\title{
How Do Energy Demand and Socioeconomic Factors Drive Localities Towards Deforestation and Carbon Emissions in Pakistan?
}

\author{
Muhammad Tufail \\ National University of Sciences and Technology \\ Shahzad Alvi ( $\nabla$ shahzad.alvi@s3h.nust.edu.pk) \\ National University of Sciences and Technology https://orcid.org/0000-0002-1565-2517 \\ Umer Khayam \\ National University of Sciences and Technology \\ Ather Maqsood Ahmed \\ National University of Sciences and Technology
}

Research Article

Keywords: Deforestation, carbon emissions, energy consumption, socio-economic, Pakistan

Posted Date: May 17th, 2021

DOl: https://doi.org/10.21203/rs.3.rs-465144/v1

License: (9) (i) This work is licensed under a Creative Commons Attribution 4.0 International License. Read Full License 


\section{Abstract}

Pakistan, the $6^{\text {th }}$ most populous country in the world is also classified as the $7^{\text {th }}$ most-affected by climate change. To blame is the ever-rising population growth, leading to higher energy demand that is dragging the rural communities towards forest resource depletion in order to meet household energy needs. It is impacting an already limited $4 \%$ of the country's forest reserves and excessive carbon emissions. This research has analyzed deforestation rate, biomass and carbon losses, and $\mathrm{CO}_{2}$ emissions in the Malakand Division, Pakistan. The data sources and models used were Landsat (8), GIS, and Remote Sensing, coupled with self-administered 521 household questionnaires deployed in 23 villages in the proximity of forest land. The results confirmed deforestation at the rate of $0.74 \% \mathrm{yr}^{-1}$, corresponding to the total emission of 1352055.64 $\mathrm{MgCO}_{2 \text { eq }} \mathrm{yr}^{-1}$ over a period of 17 years (2000-17). The risk of losing forest resources stands at 8141 species $\mathrm{yr}^{-1}$. The drivers behind deforestation found were fuelwood collection up-to $8501720 \mathrm{~kg}$ to meet the energy needs of households and commercial activities. The reasons behind this exhaustive deforestation and carbon emissions as per the household survey were abridged formal sector, low off-farm wages, and non-availability of credits to shift to other sources of income which has also affected the affordability of the social services. The study calls for the provision of alternative livelihood opportunities and effective forest management on the REDD+ mechanism to protect forest resources and address global warming.

\section{Introduction}

Forests are the critical elements in maintaining the carbon cycle. They are the largest source of carbon sink/sequestration in the open environment that preserves air quality (Coulston et al., 2015; Espirito-Santo et al., 2014). On the contrary, the global problem of deforestation and forest degradation is predominantly faced with Land Use Land Cover Changes (LULCC), thus accounting for 17-25\% of the Greenhouse Gasses (GHGs) (Le Quéré et al., 2015; Bernstein et al., 2008). The deforestation resultant carbon emissions up to $1.2 \mathrm{Pg} \mathrm{C} \mathrm{yr}^{-1}$ have been threatening (regional and global) motives of land and forest management (Joshua et al., 2017; Van der Werf et al., 2009).

Globally, the forest land has been converted into other land categories (e.g., infrastructure land) as foremost human activity has fluctuated the stock of forest carbon (Zhou et al., 2013; Pan et al., 2011). This fluctuation has led the world to excessive forest land conversion, owing to deforestation and emission of $156 \mathrm{Pg} \mathrm{C}$ into the open atmosphere during 1850-2005 time period (Houghton, 2003). Changes in land use, therefore, are the significant contributors to climate change and global warming on transmitting $\mathrm{CO}_{2}$ and other $\mathrm{GHGs}$ (Baccini et al., 2012a). This complex and increasing issue gives rise to a key problem for the research community in the field (Thompson et al., 2011).

In the debate of LULCC, industrialization, commercialization, land exploitive agricultural practices, etc. have been drastically changing the natural atmosphere due to their greater share of $\mathrm{CO}_{2}$ emissions, besides issue like soil erosion, flooding, biodiversity loss, and disturbing the water cycle (Espindola et al., 2011; Keenan et al., 2015). More recently (2016-2017) the world is faced with $\mathrm{CO}_{2}$ emissions equal to the average $\mathrm{CO}_{2}$ emissions over the last complete decade (2000-2010) (WMO, 2018). Furthermore, $\mathrm{CO}_{2}$ concentration is forecasted to double by 2030 , followed by a subsequent $1.5-4.5^{\circ} \mathrm{C}$ rise in $\mathrm{Global}$ Mean Temperature (GMT) (Balogh, 2020). The rise in GMT due to deforestation (over 13 million hectors/year) is further linked to biodiversity loss and disturbance in water regulations (Baccini et al., 2012a). Reversing or reducing deforestation is a very complex process due to the fundamental factors; agricultural expansion, development of infrastructure, timber extraction, and additional set of complex institutional, governmental and specific regional factors (Stren, et al., 2006; Eliasch, 2008; Olsen and Bishop 2009).

As there are multiple drivers of deforestation and forest degradation in nature (Geist and Lambin, 2001; Mitsuda and Ito, 2011; Meyfroidt, 2016), therefore, all such factors are divided into natural and anthropogenic causes (FAO., 2010; Macedo et al. 2012; Barona et al., 2010; Arima et al., 2011; Carr and Burgdorfer, 2013). Although, the anthropogenic factors fluctuate across geographical areas (Herald et al., 2012; Boucher et al., 2011; Kissinger et al., 2012), yet the specific anthropogenic 
factors behind deforestation are: miss-managed agricultural activities (Barber et al., 2014; Araujo et al., 2011; Macedo et al. 2012, and Assuncao et al., 2013a), commercial agriculture, mining, infrastructure (i.e., road networks and housing) and timber logging (Tegegne et al., 2016; Epule et al., 2014; Barber et al., 2014; Celine et al., 2013; Megevand et al., 2013; Dkamela, 2010; Duveiller et al., 2008; Pfaff et al., 2007). In the natural category, the reasons behind the issue found are; forest fire, drought, earthquake, forest diseases, and flooding (Gayen and Saha, 2018).

Whether natural and/or anthropogenic, the issue of deforestation and forest degradation is common to both South and Southeast Asia (in the Asian continent) that includes both (legal and illegal) unsustainable selective logging, agricultural expansion, subsistence agriculture, overgrazing, encroachments, extraction of forest wood for fuel, charcoal and construction projects (Gayen and Saha, 2018; Bahugunaa et al., 2016; Stibig et al., 2014; Hosonuma et al., 2012; Kissinger et al., 2012; Reddy et al., 2009; Lele and Joshi, 2009). Deforestation and its irreplaceable consequences (e.g., biodiversity loss, soil erosion, disruption in water cycle) are the familiar sources of unemployment and rural poverty (Meyfroidt et al., 2013; Kissinger et al., 2012; Espindola et al., 2011). Here, Hansen et al., (2012) revealed that fuelwood energy and subsistence agriculture are the leading cause of deforestation and forest degradation in the South-Asia. The intensity of the issue in region is linked to socio-economics of the rural societies as deforestation contributes to the local community's income generation, energy use, and cleared land for subsistence agriculture. As a significant source of income and energy in the rural settings including South-Asia, around 1.2 billion people are dependent on agro-forestry, while over 60 million people generate their income and energy from the forest resources (Tufail et al., 2020; Insaidoo et al., 2012; Gorte and Sheikh, 2010; World Bank, 2003). This fast phase deforestation and forest degradation phenomena in the developing countries are contributing towards $18-20 \%$ of the total global GHG emissions leading to global warming (Insaidoo et al, 2012; Owusu et al, 2011).

In South-Asian region, the depletion of forest reserves remains a well-established trend in Pakistan (Tufail et al., 2021; FAO, 2007, 2015; Tariq et al., 2014; Ahmad et al., 2012; Nazir and Olabisi 2012; Ahmad and Abbasi 2011). Pakistan is experiencing a declining trend in forest cover, up to 28,000 ha annually (FAO, 2009). The situation is even more drastic in the forest-rich areas of Pakistan (e.g., Chitral) (Qamer et al., 2015; Shehzad et al., 2014). The reasons behind deforestation and forest degradation in Pakistan are linked mainly to socio-economic factors like conversion of land for agriculture, population growth construction for dwellings, commercial activities, poverty, lack of participatory governance mechanisms for forest conservation, etc. and despite the ban imposed by the provincial government of Khyber Pakhtunkhwa (KP), the situation continues to exacerbate (Haq et al, 2018; Nazir, 2009; Suleri, 2002). It remains pertinent that in the face of measures (KP green growth project, billion tree tsunami) taken by the federal/provincial public forest degradation has been hampering the country's natural capital.

\subsection{Problem Statement}

At the provincial level in Pakistan, over $40 \%$ of forests are located in junks in the mountainous/northern areas of KP province. In the northern areas, Malakand Division has dense forest resources. The distribution of forest covers across districts in the Malakand division) are 58\% in Upper Dir, 52\% in Swat, 48\% in Shangla, 26\% in Lower Dir, 25\% in Buner, and $14 \%$ in Malakand district (GoP, 2017). The status of forest in Malakand Division by the legal definition is $7.6 \%$ as reserved, $29.7 \%$ as communal forest, and $62.7 \%$ as protected forests. The reserved forests are in the jurisdiction of the state and communal forests are retained by the local communities or individual families. Protected forests are claimed by both the government and local communities and they are in the transitional phase of land settlement. The protected forests belong to rulers of the princely states of Chitral, Dir, and Swat that were then transferred as the State property. These protected forests have been severely deforested by the local communities due to the legally accepted rights for construction, energy, and grazing purpose.

Owing to the growing demand for timber and timber products, the price of such forest products has increased sharply in the recent past. It has led to the illegal extraction of this non-renewable forest resource. Timber mafia (gangs, partly in 
cooperation with larger communal owners, contractors, and trader) was involved in the illegal extraction of forest resources. Hence, the illegal activities had started shrinking the forest area by $16.4 \%$ in Lower and Upper Dir, $31.8 \%$ in District Buner, and 14.9\% in Swat and Shangla by 2010 (INRMP, 2010). Several studies conducted on individual districts (Qamar et al., 2016, 2012; Amir et al., 2015; Rahman et al., 2014; Tariq et al, 2014; Qasim et al., 2013, 2011) reported a decrease of forest area between 1997-2007, mainly due to agricultural expansion, increase in buildup area, agricultural activities, fuelwood consumption, etc. There exists a contrast in the findings of these independent studies and government statistics where forest area shows increase because of afforestation, agroforestry, and controlling the illegal logging (UNEP \& ICIMOD, 1998, pp 29-31).

Conifer forest resources in the region have been severely threatened due to fuelwood and timber collection for both subsistence and commercial purposes, besides its conversion into agricultural fields. The dependence on forest resources also remains high due to low (avg.) agricultural productivity (equal to $1382 \mathrm{~kg} / \mathrm{ha}$ of wheat, compared to $2264 \mathrm{~kg} / \mathrm{ha}$ in $\mathrm{KP}$ and $2797 \mathrm{~kg} / \mathrm{ha}$ in Pakistan) (GoKP, 2015). Also, the official forest reference levels and forest reference emissions levels are not yet available, despite recent technological advances (Lopes et al. 2019).

The local inhabitants mainly rely on forests to complement the $\mathrm{HH}$ energy needs, construction materials, commercial needs, subsistence, and cash needs. The problem is intensified by population growth (4.1\% during 1998-2017 and higher population density of 409.59 persons $/ \mathrm{km}_{2}$ compared to national avg. of 235.76 persons $\left./ \mathrm{km}_{2}\right)(\mathrm{GoP}, 2017)$. Most of the rural population lacks the necessities of daily life in these districts. The main sources of earning are the subsistence agriculture, livestock grazing, fuel, and wood collection, that are posing an additional pressure on forests for an increased demand of fuelwood (a source of $\mathrm{HH}$ energy), foods (additional pressure on agricultural land and productivity), and construction (increased demand for houses and market expansion). In this context, HHs in the periphery of forests are the major causes of deforestation and forest degradation due to conversion of forest areas into farmlands, illegal encroachments, logging, and extensive extraction of forest products for local and commercial purposes.

The current study aimed to evaluate the level of deforestation and resultant $\mathrm{CO}_{2}$ emissions, coupled extrapolating reasons behind the observed losses in the selected districts of Malakand Division, KP province. The specific questions this study tried to answer are:

1. What was the deforestation rate for 2000,2010 , and 2017 in the study regions?

2. What were the level of fuelwood collection and timber harvesting?

3. What were the socio-economic factors driving the locality towards deforestation and forest degradation?

\section{Research Methodology}

\subsection{Study Area and Resources}

This research study was conducted in the Malakand Division, Khyber-Pakhtunkhwa province, located at $34.15^{0}$ to $35.90^{0}$ latitude and $71.50^{\circ}$ to $73.00^{\circ}$ longitude (FAO, 2016). Malakand Division has forests on an extended area that range from high altitude conifer forest occupying the heights ranging from $1550 \mathrm{~m}$ to $3300 \mathrm{~m}$ in the western Himalaya to Hindu Kush Mountains. The area is also rich with Oaks which cover the temperate zone (at an altitude of $1500 \mathrm{~m}$ to $3000 \mathrm{~m}$ ) and alpine scrub and sub-alpine forests (at an altitude of $3600 \mathrm{~m}$ to $4900 \mathrm{~m}$ ). The area has diverse ecosystems with forests, alpine pastures, shrubs, bushes, rangeland, and agriculture land at high mountainous altitudes. The temperature is low in winter (up to $-10^{\circ} \mathrm{C}$ ). This study was conducted in six districts of Malakand Division, namely; Buner, Lower Dir, Upper Dir, Malakand, and Swat (Fig. 1). The population of Malakand division residing in an area of $29,871 \mathrm{~km}^{2}$ is 7.5 million (GoP, 2017). In-total 23 villages were selected within these six districts for data collection (Table 1). 
Table 1

Name of the villages surveyed in each district

\begin{tabular}{|c|c|c|c|c|c|}
\hline \\
\hline District & S. No & Villages & District & S. No & Villages \\
\hline \multirow[t]{3}{*}{ Buner } & 1 & Bar Gokand & \multirow[t]{2}{*}{ Shangla } & 12 & Dawlat Kaly \\
\hline & 2 & Dokada Kaly & & 13 & Malak Khail \\
\hline & 3 & Naway Kaly & \multirow[t]{4}{*}{ Swat } & 14 & Kalam \\
\hline \multirow[t]{3}{*}{ Lower Dir } & 4 & Ziarat Talash & & 15 & Miandam \\
\hline & 5 & Maskeni & & 16 & Puchaar \\
\hline & 6 & Asbanrh & & 17 & Shalhand \\
\hline \multirow[t]{3}{*}{ Malakand } & 7 & Maikhband & \multirow[t]{6}{*}{ Upper Dir } & 18 & Tall \\
\hline & 8 & Pir Khairl & & 19 & Kalkot \\
\hline & 9 & Qalangi & & 20 & Gwaldai \\
\hline \multirow[t]{3}{*}{ Shangla } & 10 & Alpuri & & 21 & Barawal \\
\hline & 11 & Damorai & & 22 & Dogdara \\
\hline & & & & 23 & Malak Abad \\
\hline
\end{tabular}

\subsection{Ecological regions of Malakand Division}

Malakand division constitutes five ecological regions; Himalayan Subtropical Pine Forests, Western Himalayan Sub-Alpine Conifer Forests, Baluchistan Xeric Woodlands, Karakoram-West Tibetan Plateau Alpine Steppe, and Northwestern Himalayan Alpine Shrub and Meadows. Most of the forests consist of conifers of the Western Himalayan Subalpine Conifer Forest ecoregion (WWF reference maps). The most common stands are composed of fir, pure or mixed with oaks, or assemblages of fir and birch, pine and spruce, or cypress and cedar (Qamer et al., 2016). Also, being a crucial ecosystem for livelihoods, these forests have high conservation value (e.g., habitat for protected migratory birds).

\subsection{Data Sources and Techniques}

Several data sources have been used to compile a geographic database with the biophysical attributes of the area. For land cover, maps of 2000 and 2010 extracted from the maps database of the International Center for Integrated Mountain Development (ICIMOD) have been used. Maps for 2017 were constructed using Landsat-8 (L8) imagery. Three Landsat scenes that cover the study area are listed in Table 2. The mosaic was produced in Google Earth Engine API (GEE) and all bands have $30 \mathrm{~m}$ resolution.

Table 2

Landsat 8 data used to build the 2017 mosaic over the study area.

\begin{tabular}{|c|c|c|c|}
\hline Path_Row & $\begin{array}{l}\text { Date } \\
\text { (dd-mm-yyyy) }\end{array}$ & Cloud Cover (\%) & Image ID in Earth Engine \\
\hline 150_36 & 27-10-2017 & 2.13 & LANDSAT/LC08/C01/T1_TOA/LC08_150036_20171027 \\
\hline 151_35 & $18-10-2017$ & 4.15 & LANDSAT/LC08/C01/T1_TOA/LC08_151035_20171018 \\
\hline 151_36 & $18-10-2017$ & 0.54 & LANDSAT/LC08/C01/T1_TOA/LC08_151036_20171018 \\
\hline
\end{tabular}

The Digital Elevation Model (DEM) from the Shuttle Radar Topography Mission (SRTM) with $30 \mathrm{~m}$ resolution was used to improve the classification results. From this dataset, elevation, slope, and aspect were obtained and then added as bands to 
the 2017 mosaic. The values of elevation, slope, and aspect were normalized to the same range as the L8 bands and then added to the mosaic. The bands included in the final mosaic are listed in Table 3.

Table 3

Final bands of the 2017 mosaic.

\begin{tabular}{|llll|}
\hline \# Band & Sensor & Band description & Resolution (m) \\
\hline $\mathbf{1}$ & Landsat 8 & Band 2 (blue) & 30 \\
\hline $\mathbf{2}$ & Landsat 8 & Band 3 (green) & 30 \\
\hline $\mathbf{3}$ & Landsat 8 & Band 4 (red) & 30 \\
\hline $\mathbf{4}$ & Landsat 8 & Band 5 (NIR) & 30 \\
\hline $\mathbf{5}$ & Landsat 8 & Band 6 (SWIR 1) & 30 \\
\hline $\mathbf{6}$ & Landsat 8 & Band 7 (SWIR 2) & 30 \\
\hline $\mathbf{7}$ & Shuttle Radar Topography Mission & Elevation & 30 \\
\hline $\mathbf{8}$ & Shuttle Radar Topography Mission & Slope & 30 \\
\hline $\mathbf{9}$ & Shuttle Radar Topography Mission & Aspect & 30 \\
\hline
\end{tabular}

\subsubsection{Processing of Data}

The Landsat imagery (cost-effective and accessible) for the years 2000, 2010, and 2017 were taken where dates fall within the dry season of the whole study area. The choice of dry season images was made due to minimum cloud cover and less vegetation moistness in the season. It helped to determine forest types, identify agricultural forms, and classify pastures. The image of 2000 was geometrically corrected using a map scale of 1: 50,000 of the study areas obtained from UTM (Universal Transverse Mercator) Zone 84 World Geodetic System (WGS) 1984. Points from the image 2000 were rectified and then used to register the images of 2010 and 2017, maintaining the RMS (Root Mean Square) error of each registration below 0.5 pixels $(<15 \mathrm{~m})$. The images were corrected for the sensor, atmospheric, and illumination variance sources by radiometric calibration, as suggested in the domain (Green and Hanson, 2002). The Maps of ICIMOD for the years 2000 and 2010 were reclassified initially from 12 classes to 6 classes (All the six forest types were combined in one class, agriculture and agriculture fellow land were combined in one class, and further classes were kept unchanged) and then to four main classes ( Here. water bodies, snow, and other land classes were kept as zero (0) class) to obtain results' accuracy. The classes of snow and water acted as a mask for the 2000 and 2010 maps. For the 2017 maps, the training areas collected in QGIS were imported into Google Earth Engine (GEE), where the mosaic was classified (For the classification, the number of trees was set to 100 and the remaining arguments were left with the default values. However, before the classification, cloud was removed from the image by creating a mask that was further applied to all images) using the Random Forest Classifier with "ee.Classifier.randomForest" method.

The change map between 2000-2010, and 2010-2017 was produced using the Semi-Automatic Classification Plugin (SCPPlugin) in Quantum GIS (QGIS). The non-forest areas (wetlands, built, agriculture, and pasture) were merged into the NonForest (NF) final class. The remaining images were classified through comparison with signature mean plots of 2000 classes and contrasting vegetation using the Normalized Difference Vegetation Index (NDVI) and the thermal band of each image. The result of the classification process was the creation of "Forest" (F) and "Non-Forest" (NF) classifications for each image data. For map algebra and validation of the change, maps for the study periods: P1: 2000-2010 and P2: 2010-2017, the Olofsson et al., (2014) method was used to adjust the areas of change and compute the margins of error. The districtwise analysis was done using the change maps 2000-2010 and 2010-2017 in "R". Deforestation rates were obtained from the Land Use Land Cover Changes (LULCC) of 2000, 2010, and 2017 maps. The 2000 map was used as a baseline map for obtaining the deforestation rate. For the first period 2000-2010 the deforestation obtained using maps algebra by 
subtracting 2010 map from 2000 map. Similarly, the deforestation rate for the second period obtained by subtracting the 2017 map from the 2010 map.

The total forest area was calculated for each district from the land use land cover change analysis. For an estimation of carbon stock, the biomass is converted into carbon, using the global carbon measuring factor (0.47) (Pandey et al. 2016; Zhang et al. 2013; Haripriva, 2000; IPCC, 2006a). While nationally adopted carbon measuring factor (0.5) has been used (Saeed et al. 2016; Ahmad et al. 2014; Nizami, 2012). Deforestation in the study area resulted in the conversion of forest land into other lands uses, such as forest land to agriculture land, rangeland, barren land, and settlement. So, the net

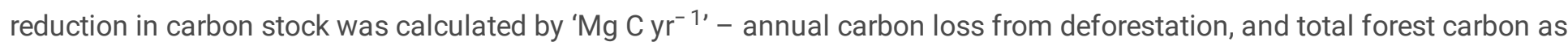
$\mathrm{Mg} \mathrm{Cha}{ }^{-1}$ (before deforestation and after deforestation, i.e., total forest area converted to other lands in hectare (Philip, 1994). The baseline for biomass loss per hector and resultant $\mathrm{CO}_{2}$ emissions factor were referred which were; $258.98 \mathrm{Mg}$ ha $^{-1}$ (biomass loss) and $129.49 \mathrm{Mg} \mathrm{ha}^{-1}$ (mean carbon stock release) (Ahmad et al., 2014).

\subsection{Socio-Economic Survey \& Data Analysis}

The literature suggests the existence of several direct and indirect socio-economic drivers of deforestation. These drivers are classified as; agricultural expansion (subsistence and commercial agriculture), wood extraction (fuelwood and construction timber), market expansion (households' construction and commercial expansion), and demographic, economic, political, and institutional factors (Tufail et al., 2021; Irfan et al., 2017; Qamer et al., 2016; Qamer et al, 2012; Ali et al., 2006; Ali and Benjamin 2004; Gautam et al., 2003). The same drivers as variables were taken to study the socio-economic causes of deforestation and forest degradation in the study region (Table 4). For this reason, a field survey was conducted at households $(\mathrm{HH}$; A household is defined as "the people sharing the same house boundary wall and using the same kitchen or cooking and sharing meals) in the peripheries/villages (i.e., within $6 \mathrm{~km}$ as communal rights on the forest which changes even within four to five-kilometer range) of the natural forests in the study area. Due to the remoteness, diversity and inaccessibility of most parts/villages/farflung areas, it was impossible to include every village in the survey. Thus, sampling of accessable villages helped to reflect the most representative combinations of geographical and socioeconomic situations in the region.

It was to establish the relative value ( It's the value that is directly extracted from the forests (by local communities) for their livelihood, compared to other income sources) of the goods and services in the forests' vicinity. Before administring the final refined questionnaire (May-June 2017 and August-September 2017,), which was easy to understand and attempt, a pilot survey was implemented (in March 2017) amongst randomly selected households in 3 different villages in 2 Districts, i.e., Lower Dir and Malakand. In total 521 self-administered (close-ended) questionnaires were collected at HH level covering six main topics (Table 5): (1) HH demographics; (2) agricultural output and type of energy inputs commonly used; (3) fuel-wood collection patterns; (4) type/quantity of non-timber forest products and other goods extracted from the forests; (5) sources of income; and (6) timber extraction and transportation. Here, standardized techniques of Fowler and Mangione (1990) helped to minimize errors that could be associated with the data collection process. The basic data about the location of forests and villages (in the proximity) were obtained from the District Forest Office (DFO) and Range Forest Officer (RFO). The data collected through the questionnaires were then organized in a spreadsheet for quality screening. 
Independent and Dependent Variables with Sources

\begin{tabular}{|c|c|c|}
\hline Variable & Description & Source \\
\hline \multicolumn{3}{|l|}{$\begin{array}{l}\text { Independent } \\
\text { Variables }\end{array}$} \\
\hline $\begin{array}{l}\text { HH Resident } \\
\text { Duration }\end{array}$ & The number of years living in the peripheries of Forest & $\begin{array}{l}\text { Garekae et al., (2017); Veldeld et al., } \\
\text { (2004) }\end{array}$ \\
\hline HH Size & The total number of household's member & $\begin{array}{l}\text { Mamo et al., (2007); Bwalya (2011), } \\
\text { Veldeld et al., (2004); Shively (2001) }\end{array}$ \\
\hline Education & $\begin{array}{l}\text { The number of years of education attained, illiterate }=0 \text {, } \\
\text { Primary }=1, \text { Middle }=2, \ldots \text { master's degree }=6\end{array}$ & $\begin{array}{l}\text { Gunatilake and Chakavorty (2003); } \\
\text { Veldeld et al., (2004) }\end{array}$ \\
\hline Nutrition & $\begin{array}{l}\text { Nutrition, Very Poor Health Condition }=0 \text {, Poor Health }=1 \text {, } \\
\text { Moderate Health }=2 \text {, and Excellent Health }=3\end{array}$ & Gunatilake and Chakavorty (2003) \\
\hline Wages & $\begin{array}{l}\text { Number of Pakistani Rupees Received/ daily, converted to } \\
\text { monthly, and average annual rupees }\end{array}$ & Bwalya (2011); Mamo et al., (2007) \\
\hline $\begin{array}{l}\text { NTFP's } \\
\text { Income }\end{array}$ & $\begin{array}{l}\text { The annual values of Non-timber Forest Products collected } \\
\text { by the household }\end{array}$ & $\begin{array}{l}\text { Neumann and Hirsch (2010); Gunatilake } \\
\text { and Chakavorty (2003) }\end{array}$ \\
\hline $\begin{array}{l}\text { Other } \\
\text { Sources of } \\
\text { Income }\end{array}$ & $\begin{array}{l}\text { Remittances, Income from small business, and Benazir } \\
\text { Income Support Program }\end{array}$ & Bwalya (2011) \\
\hline $\begin{array}{l}\text { Agricultural } \\
\text { Efficiency }\end{array}$ & It was Measured using DEA Analysis & Ji and Lee (2014) \\
\hline $\begin{array}{l}\text { Fuelwood } \\
\text { Prices }\end{array}$ & $\begin{array}{l}\text { Prices at which households sell the fuelwood collected in } \\
\text { local shops }\end{array}$ & Heltberg (2000); Amacher et al., (1999) \\
\hline $\begin{array}{l}\text { Access to } \\
\text { Credit }\end{array}$ & $\begin{array}{l}\text { Access to both formal and informal credit yes }=1 \text {, and No } \\
=0\end{array}$ & Badola (1998) \\
\hline $\begin{array}{l}\text { Accessibility } \\
\text { to Forest }\end{array}$ & One-way distance to nearest forest, time taken in minutes & $\begin{array}{l}\text { Mamo et al., (2007); Veldeld et al., (2004); } \\
\text { Heltberg (2000) }\end{array}$ \\
\hline \multicolumn{3}{|l|}{$\begin{array}{l}\text { Dependent } \\
\text { Variable }\end{array}$} \\
\hline $\begin{array}{l}\text { Fuel Wood } \\
\text { used by HHs }\end{array}$ & $\begin{array}{l}\text { The amount of Fuelwood used by the households during } \\
\text { the two seasons }\end{array}$ & Heltberg (2000) \\
\hline
\end{tabular}

Table 5

$\mathrm{HH}$ surveyed in each village within the districts.

\begin{tabular}{|llll|}
\hline District & Number of Villages Surveyed & Total HHs/Villages & Number of HHs Surveyed \\
\hline Buner & 3 & 230 & 72 \\
\hline Lower Dir & 3 & 287 & 84 \\
\hline Malakand & 3 & 310 & 102 \\
\hline Shangla & 4 & 263 & 89 \\
\hline Swat & 4 & 282 & 87 \\
\hline Upper Dir & 6 & 335 & 87 \\
\hline Total & 23 & 1707 & 521 \\
\hline
\end{tabular}




\section{Results}

\subsection{Land Cover Distribution}

The land-use patterns showed forest area as; 67816.98ha, 44269.74ha, 13726.80ha, 90965.79ha, 175573.53ha, and 194563.71ha for the districts; Buner, Lower Dir, Malakand, Shangla, Swat, and Upper Dir, respectively, for the year 2000 (the reference year), 2000 and 2017. It was confirmed that the forest area was decreased considerably in 2010 (compared to 2000) coupled with an intense decrease in 2017 in all the study districts (Figures 2-4).

Table 6: Land Use and Land Cover Changes P1 (2000-2010) Area (ha).

\begin{tabular}{|lllllll|}
\hline $\mathbf{2 0 0 0 - 2 0 1 0}$ & Buner & Lower Dir & Malakand & Shangla & Swat & Upper Dir \\
\hline Class & 66539.9 & 43504.7 & 13538.6 & 89596.9 & 168520.0 & 192027.6 \\
\hline Stable Forest & 142864.0 & 149404.4 & 100428.2 & 77269.4 & 356455.4 & 234308.1 \\
\hline Stable Non-Forest & 8.3 & 0.4 & 0.0 & 14.7 & 45.5 & 7.2 \\
\hline Forest to Cropland & 684.9 & 263.3 & 90.9 & 1300.5 & 5110.4 & 1765.2 \\
\hline Forest to Grassland & 68.9 & 97.3 & 53.7 & 1897.7 & 763.7 \\
\hline Forest to Other Land & 583.9 & 501.4 & $\mathbf{1 1 4 1 5 5 . 0 1}$ & $\mathbf{1 6 8 2 3 5 . 2}$ & $\mathbf{5 3 2 0 2 8 . 8 8}$ & $\mathbf{4 2 8 8 7 1 . 7 8}$ \\
\hline Total & $\mathbf{2 1 0 6 8 1}$ & $\mathbf{1 9 3 6 7 4 . 1 5}$ & $\mathbf{1 1 4 0 . 7}$ & \\
\hline
\end{tabular}

The results of LULCC for two-period P1 (2000-10) and P2 (2010-17) showed conversion of the vast area into grassland and other lands (e.g., settlements and barren land) (Table 6). It has been observed that Swat District (relatively) lost more forest area, followed by Upper Dir and Shangla Districts - forest area of 5110.4 Hactare (ha) in Swat, 1765.2 ha in Upper Dir, and 1300.5 ha in Shangla has already been converted into grassland. Also, the forest area converted to settlement and barren land also remained high (i.e., 1897.7 ha in Swat, followed by 763.7 ha and 583.9 ha in Upper Dir and Buner, respectively).

The land-use change analysis for the P2 also confirmed the conversion of forest area (11790.5 ha) to agriculture land in Swat - the highest in all districts. Whereas, 382.5 ha area was converted into agriculture land in Malakand - the lowest in the whole study area. Similarly, 28422.6 ha of forest land was converted to grassland in Buner, followed by 16967.3 ha in Swat - both the highest figures. Also, 9786.2 ha of forest land was converted to grassland in Malakand. Conversion of forest land to other lands in P2 has increased in the two districts, i.e., Malakand and Shangla, while in all other districts namely, Buner, Lower Dir, Swat, and Upper Dir experienced a decreased trend (Table 7). It is, therefore, confirmed that the whole study area suffered from significant land-use changes, hence the conversion of forest land to other land categories between P1 (2000-10) and P2 (2010-17) see Figures 5 and 6.

Table 7: LULCC P2 (2010-2017) - Area change (ha). 


\begin{tabular}{|c|c|c|c|c|c|c|}
\hline \multicolumn{7}{|l|}{ 2010-2017 } \\
\hline Class & Buner & Lower Dir & Malakand & Shangla & Swat & Upper Dir \\
\hline Stable Forest & 32294.6 & 23249.9 & 2893.7 & 69820.3 & 139367.9 & 169983.9 \\
\hline Stable Non-Forest & 144141.1 & 150169.4 & 100616.4 & 78638.3 & 363508.9 & 236844.2 \\
\hline Forest to Cropland & 5571.9 & 4367.3 & 382.5 & 8086.9 & 11790.5 & 9328.5 \\
\hline Forest to Grassland & 28422.6 & 15560.5 & 9786.2 & 11584.9 & 16967.3 & 12356.0 \\
\hline Forest to Other Land & 250.7 & 327.1 & 476.3 & 104.9 & 394.3 & 359.2 \\
\hline Total & 210681 & 193674.15 & 114155.01 & 168235.2 & 532028.88 & 428871.78 \\
\hline
\end{tabular}

The average deforestation rate in the study area remained $0.63 \%$ in $\mathrm{P} 1$ and $0.84 \%$ in $\mathrm{P} 2$. A high deforestation rate was seen in Lower Dir, followed by Shangla and Upper Dir. Opposite to this the lowest rate of deforestation was in the district Malakand in P1. It has been observed that the deforestation rate slightly decreased in Lower Dir, Upper Dir, and Buner in the second period but increased in Malakand and Shangla region in P2 (Table 8). It is established that the study region has lost a total of 108921.16 ha at the rate of $0.63 \%$ annually in $\mathrm{P} 1$ and 98223.63 ha at the rate of $0.84 \%$ per annum in P2 (Table 8 ). The description of Figure 7 showed the comparison of the deforestation rate between the P1 and P2. The figure suggested that the deforestation rate has increased at an alarming rate in District Malakand and Shangla. In contrast, it has significantly decreased in District Buner and slightly decreases in District Upper Dir, Swat, and Lower Dir.

Table 8: District wise annual Deforestation rate and Forest area converted to other land use

\begin{tabular}{|lllll|}
\hline & $\mathbf{2 0 0 0 - 2 0 1 0}$ & \multicolumn{3}{l|}{$\mathbf{2 0 1 0 - 2 0 1 7}$} \\
\hline District & Deforestation Rate \% $\mathbf{~ r ~}^{-1}$ & Area (ha) $\mathbf{~ y r}^{-1}$ & Deforestation Rate \% $\mathbf{~ r ~}^{-1}$ & Area (ha) $\mathbf{~ r ~}^{-1}$ \\
\hline Buner & 0.61 & 15245.32 & 0.35 & 13089.86 \\
\hline Lower Dir & 1.07 & 13801.02 & 0.95 & 13744.32 \\
\hline Malakand & 0.16 & 9913.90 & 0.72 & 9480.64 \\
\hline Shangla & 0.76 & 9408.32 & 2.09 & 7730.12 \\
\hline Swat & 0.54 & 39140.56 & 0.50 & 32744.56 \\
\hline Upper Dir & 0.64 & 21412.04 & 0.59 & 21434.13 \\
\hline
\end{tabular}

\subsection{Level and Reasons behind Biomass Loss, Carbon Loss, and Carbon Emissions}

The results have confirmed the highest biomass stock and forest cover in the baseline year 2000 i.e., $50388109.62 \mathrm{Mg}$, 45470032.80 Mg, and 23558320.29 Mg found in Upper Dir, Swat, and Shangla, respectively. The biomass stock in Buner, Lower Dir, and Malakand in the period 2000 was $17563241.48 \mathrm{Mg}, 11464977.27 \mathrm{Mg}, 3554966.66 \mathrm{Mg}$. However, the area has suffered from a decreasing trend in total biomass in all the study districts for P2 (Table 9). The estimated biomass loss (due to deforestation and forest degradation) for P1 remained 1827633.56 Mg in Swat, 656801.77 Mg in Upper Dir, and 354517.72 Mg in Shangla (Table 7). Other areas like Buner, Lower Dir, and Malakand experienced biomass loss of up to 330743.36 Mg, 198119.70 Mg, and 48737.45 Mg, respectively. It was confirmed that biomass loss has increased in P2 (2010-17). Similarly, carbon stock loss was recorded to be highest in Swat for both P1 and P2 (i.e., 858564.77 Mg in 2000-10 and 1483133.86 Mg in 2010-17). Swat was followed by Upper Dir: 308696.83 Mg in P1 and 1179191.44 Mg in P2; Shangla 
166623.33 Mg in P1 and 997099.86 Mg in P2. Other study districts also experienced similar patterns of carbon loss in both P1 and P2 (Table 10).

Similarly, total $\mathrm{CO}_{2}$ emission due to deforestation was estimated at $3142347.07 \mathrm{MgC}, 1129830.40 \mathrm{MgC}$, and 609841.39 $\mathrm{MgC}$ in Swat, Upper Dir, and Shangla in P1. Whereas, for the same study period, the $\mathrm{CO}_{2}$ emission in Buner, Lower Dir, and Malakand remained as $568944.72 \mathrm{MgC}, 340805.51 \mathrm{MgC}$, and $83838.15 \mathrm{MgC}$, respectively. Yet, carbon emissions intensified for P2 confirmed an increased rate of deforestation (Table 10). Furthermore, biomass and carbon loss from timber harvesting and fuelwood harvesting were the main reasons behind the problem (Table 11). The values of the losses from commercial wood harvesting estimated to be $1288.10 \mathrm{Mg}, 651.28 \mathrm{Mg}$, and $540.40 \mathrm{Mg}$ in Swat, Malakand, and Buner, respectively (The value of biomass and carbon stock was calculated from household's integrated survey using factor 0.5 for biomass and 0.47 for carbon). Whereas, the same losses due to fuelwood harvesting were linked to HHs' primary energy source of the community-dwelling in the peripheries of forests. The difference in biomass and carbon loss from commercial wood harvesting in the study region was also linked to exogenous (timber mafia) factors. This extensive and uncontrolled loss of biomass (due to deforestation and forest degradation) and carbon emissions are reinforcing global phenomenon in lieu of HH fuelwood consumption (Ahmad et al., 2018). So, it remains imperative to explore the actual causes of the problem along with its severity in the region.

Table 9: Total biomass and carbon stock for the year; 2000, 2010, and 2017.

\begin{tabular}{|c|c|c|c|c|c|c|}
\hline \multirow[b]{2}{*}{ District } & \multicolumn{3}{|c|}{ Total Biomass (Mg) } & \multicolumn{3}{|c|}{ Carbon Stock (Mg) } \\
\hline & 2000 & 2010 & 2017 & 2000 & 2010 & 2017 \\
\hline Buner & 17563241.48 & 17232498.12 & 15724550.82 & 8254723.50 & 8099274.12 & 7390538.88 \\
\hline Lower Dir & 11464977.27 & 11266857.57 & 10051101.85 & 5388539.31 & 5295423.06 & 4724017.87 \\
\hline Malakand & 3554966.66 & 3506229.22 & 3283822.37 & 1670834.33 & 1647927.73 & 1543396.52 \\
\hline Shangla & 23558320.29 & 23203802.57 & 21082313.52 & 11072410.54 & 10905787.21 & 9908687.35 \\
\hline Swat & 45470032.80 & 43643299.24 & 40487695.28 & 21370915.42 & 20512350.64 & 19029216.78 \\
\hline Upper Dir & 50388109.62 & 49731307.85 & 47222389.89 & 23682411.52 & 23373714.69 & 22194523.25 \\
\hline
\end{tabular}

Table 10: Biomass loss, carbon loss, and $\mathrm{CO}_{2}$ emission for the period; 2000-10 and 2010-17.

\begin{tabular}{|lllllll|}
\hline & \multicolumn{2}{l}{ Biomass Loss $(\mathrm{Mg})$} & \multicolumn{2}{l}{ Carbon Loss $(\mathrm{Mg})$} & \multicolumn{2}{l|}{ CO $_{2}$ Emission $(\mathrm{Mg})$} \\
\hline District & $\mathbf{2 0 0 0 - 2 0 1 0}$ & $\mathbf{2 0 1 0 - 2 0 1 7}$ & $\mathbf{2 0 0 0 - 2 0 1 0}$ & $\mathbf{2 0 1 0 - 2 0 1 7}$ & $\mathbf{2 0 0 0 - 2 0 1 0}$ & $\mathbf{2 0 1 0 - 2 0 1 7}$ \\
\hline Buner & 330743.36 & 1507947.31 & 155449.38 & 708735.23 & 568944.72 & 2593970.96 \\
\hline Lower Dir & 198119.70 & 1215755.71 & 93116.26 & 571405.18 & 340805.51 & 2091342.98 \\
\hline Malakand & 48737.45 & 222406.84 & 22906.60 & 104531.22 & 83838.15 & 382584.25 \\
\hline Shangla & 354517.72 & 2121489.06 & 166623.33 & 997099.86 & 609841.39 & 3649385.47 \\
\hline Swat & 1826733.56 & 3155603.97 & 858564.77 & 1483133.86 & 3142347.07 & 5428269.94 \\
\hline Upper Dir & 656801.77 & 2508917.96 & 308696.83 & 1179191.44 & 1129830.40 & 4315840.67 \\
\hline
\end{tabular}

Table 11: Biomass and Carbon loss from commercial and fuelwood harvesting by HHs 


\begin{tabular}{|lllll|}
\hline \multicolumn{3}{|l}{ Commercial Wood } & \multicolumn{2}{l|}{ Fuel Wood } \\
\hline Districts & Biomass Mg & Carbon Stock Mg & Biomass Mg & Carbon Stock Mg \\
\hline Buner & 540.40 & 253.99 & 491.10 & 230.82 \\
\hline Lower Dir & 183.04 & 86.03 & 668.46 & 314.18 \\
\hline Malakand & 651.28 & 306.10 & 383.91 & 180.44 \\
\hline Shangla & 436.86 & 205.32 & 665.33 & 312.70 \\
\hline Swat & 361.13 & 169.73 & 834.84 & 392.37 \\
\hline Upper Dir & 1288.10 & 605.41 & 651.13 & 306.03 \\
\hline
\end{tabular}

\subsection{Causes of Deforestation}

The results of the study revealed intensified deforestation and forest degradation problem in the whole study area, which was linked to fuelwood harvesting, with $\mathrm{HH}$ responsible for burning a total of 212543 bundles of fuelwood. Fuelwood used in Lower Dir is 53477 accounting for $25 \%$ of the total fuelwood which is the highest while in the remaining districts the fuelwood used followed a similar pattern. This extensive harvesting was to meet $\mathrm{HH}$ fuel consumption and then selling (along with Non-timber Forest Products-NTFPs) to generate income. It is coupled with un-ending forest harvesting for construction of physical infrastructure e.g., houses, shops, etc. The HH collects a total of 37031 pieces of construction timber annually, of which 31\% (11710 pieces) collection occurred in district Upper Dir followed by Malakand $22 \%$ and Buner $18 \%$. Also, issues like, illegal logging was found on the peak that has been posing incremental impact on the limited forest resources (Table 12). Furthermore, the pressure on forest resources was found linked to high population growth, forest cutting for agricultural expansion, and increased activities of residential construction.

\begin{tabular}{|lll|}
\hline Districts & Timber Collected per Year Construction) & Timber Collected per Year (Fuel) \\
\hline Buner & 6755 & 32740 \\
\hline Lower Dir & 2288 & 53477 \\
\hline Malakand & 8141 & 30713 \\
\hline Shangla & 4854 & 29570 \\
\hline Swat & 3283 & 37104 \\
\hline Upper Dir & 11710 & 28939 \\
\hline
\end{tabular}

Table 12: Wood and timber removal estimates per district

Note: type (1) Timber collection is a rectangular type of wood which is on average one piece of wood is equal to, Length $=7$ feet width $=2$, and Height $=1.5$ feet. Such types of wood have been used for furniture and construction of houses. Type (2): It is a type of wood that is collected in bundles and is mostly used for fuel energy. The weight of one bundle is equal to 50 $\mathrm{kg}$ to $100 \mathrm{~kg}$.

It remained pertinent that the non-existence of safety-nets (e.g., education and technical skills) to fight against exogenous and endogenous shocks has been driving forest behind the studied issues. The exogenous shocks (e.g., natural climates, diseases, and deaths) that imply the need for additional income, have further increased pressure on forest resources to overcome these shocks. Also, poor agricultural output that has been resulting in insufficient income proved to be an exploitive factor. 
All this coupled with a lack of management or surveillance by official institutions (i.e., forest department KP), caused in people resorting to wood, timber, and NTFPs for obtaining additional cash, food, and energy. The results further established mix relationship between the duration of the HHs' residency and fuelwood used in the study area. Education is found significantly negatively related to dependency on forest resources - the higher the education level, desto lower the dependency. The coefficient of education for district Buner, Lower Dir, Malakand, and Upper Dir were: -12.53, -19.17, -10.96, and -1.34 (significant at $5 \%$ level). While the coefficient of education for district Swat and Shangla remained: -32.63 and -15.24 (at 1\% significance level). It was related to more sensitivity and awareness towards forests' conservation, environmental health, and the possibility of a diverse pool of job opportunities. The results further reflected an inverse relationship between HH's health condition and fuelwood collection and consumption - the higher the consumption and air pollution desto higher the rate of diseases and illness.

The coefficient values (significant at 5\%) for Buner, Lower Dir, and Malakand were: 19.23, -28.90 , and -12.71 , respectively. For district Swat, it remained 40.74 (significant at 1\%). However, the results for district Shangla and Upper Dir were insignificant ( $p>0.05$ ), implying that HHs' reliance on forest resources decreases with every improvement in health conditions (as SDG\#3 good health and well-being). The empirical results of wages show a mixed picture. Theoretically, it is believed that there is a negative relationship between households' wages and their dependence on forests for energy purposes. The empirics of districts Buner, Shangla, and Upper Dir for wages showed insignificant relation ( $p>0.05)$. On the contrary, district Swat showed that daily wage increase led to a decline in HHs' use of forest fuel by PKR. 665/ year (coefficient value of 0.665 at $5 \%$ significance).

Income from NTFP showed a positive and significant relationship with forest extraction in districts: Buner and Shangla (coefficient of 0.45 and 0.85), coupled with an insignificant relationship in districts Lower Dir, Malakand, and Swat (coefficient -0.103, p>0.05). In the case of Upper Dir, the HHs mainly relied on selling forest fruits so an increase in prices led to a decrease in extraction. Here, other sources of income had a positive impact on forest extraction in district Lower Dir (coefficient of 0.168 , at $5 \%$.), whereas such impact in districts: Buner, Malakand, Swat, and Upper Dir was positive but statistically insignificant ( $p>5 \%$ ). Further, the agricultural production (second major income source) had a significantly negative impact on forest extraction in all districts as a $1 \%$ increase in the technical efficiency of agriculture had decreased $\mathrm{HH}$ income from forest extraction. Also, the empirics have revealed that fuelwood prices have a significantly negative relationship with forest product extraction in districts Malakand, Shangla, while in districts: Lower Dir, Swat, and Upper Dir the relationship was positive but statistically insignificant $(p>0.05)$.

Likewise, the results of HHs' access to credit (formal: loans institutions and informal: loans from relatives, neighbors, friends' circle, etc.) established district Buner and Malakand in positive, yet insignificant relationship with forest products' extraction ( $p>0.05$ and $5 \%$ significance level). It has demonstrated that more the credit facilities accessible, more the forest products' extraction rate. On the contrary, this relationship was negative (at significance level $5 \%$ and $1 \%$ ) in districts: Lower Dir, Shangla, and Upper Dir - more access to credit desto higher deforestation and forest degradation. Lastly, the study found unveiled that in district Buner, HHs' accessibility to the forest has a negative link with forests products extraction ((at $5 \%$, while in district Malakand the said relationship was declared negatively insignificant $(p>0.05)$. However, in districts: Lower and Upper Dir and Swat, this connection was positively significant (at $5 \%$ ). This shows that as the accessibility to forests increases so the deforestation and deforestation rate, whereas in district Shangla this association was positively insignificant $(p>0.05)$ (Table $13 a, b)$.

Table 13a: Tobit Analysis - District: Buner, Lower Dir, and Malakand 


\begin{tabular}{|c|c|c|c|c|c|c|c|c|c|}
\hline Dependent & Fuelwood u & ed by Hol & sehold. & t Analysis & & & & & \\
\hline Districts & Buner & & & Lower Dir & & & Malakand & & \\
\hline $\begin{array}{l}\text { Independent } \\
\text { Variables }\end{array}$ & Coefficient & $\begin{array}{l}\text { Std. } \\
\text { Err. }\end{array}$ & $\begin{array}{l}\mathrm{t}- \\
\text { value }\end{array}$ & Coefficient & $\begin{array}{l}\text { Std. } \\
\text { Err. }\end{array}$ & $\begin{array}{l}\mathrm{t}- \\
\text { value }\end{array}$ & Coefficient & $\begin{array}{l}\text { Std. } \\
\text { Err. }\end{array}$ & $\begin{array}{l}\mathrm{t}- \\
\text { value }\end{array}$ \\
\hline $\begin{array}{l}\text { HHS } \\
\text { Resident } \\
\text { Duration }\end{array}$ & 1.339 & 0.962 & 1.39 & 1.521 & 0.485 & 3.13 & 0.006 & 0.157 & 0.04 \\
\hline $\begin{array}{l}\text { Household } \\
\text { Size }\end{array}$ & -2.567 & 2.398 & -1.07 & -3.435 & 1.398 & -2.46 & -0.176 & 0.518 & -0.34 \\
\hline Education & -13.53 & 5.56 & -2.43 & -19.17 & 14.076 & -1.36 & -10.968 & 3.602 & -3.04 \\
\hline $\begin{array}{l}\text { Health } \\
\text { Condition }\end{array}$ & 19.273 & 8.341 & 2.31 & -28.908 & 11.853 & -2.44 & -12.715 & 4.101 & -3.1 \\
\hline Wages & 0.672 & 0.845 & 0.8 & 1.779 & 0.694 & 2.56 & -0.208 & 0.185 & -1.12 \\
\hline $\begin{array}{l}\text { NTFP's } \\
\text { Income }\end{array}$ & 0.451 & 0.167 & 2.71 & 0.002 & 0.027 & 0.09 & 0.047 & 0.067 & 0.71 \\
\hline $\begin{array}{l}\text { Other } \\
\text { Sources of } \\
\text { Income }\end{array}$ & 0.004 & 0.081 & 0.05 & 0.168 & 0.057 & 2.94 & 0.082 & 0.096 & 0.86 \\
\hline $\begin{array}{l}\text { Agricultural } \\
\text { Efficiency }\end{array}$ & -54.794 & 29.735 & -1.84 & 42.751 & 28.311 & 1.51 & -43.153 & 17.232 & -2.5 \\
\hline $\begin{array}{l}\text { Fuelwood } \\
\text { Prices }\end{array}$ & 0.056 & 0.024 & 2.4 & -0.004 & 0.023 & -0.16 & -0.094 & 0.025 & -3.67 \\
\hline $\begin{array}{l}\text { Access to } \\
\text { Credit }\end{array}$ & 20.181 & 33.703 & 0.6 & -22.448 & 11.498 & -1.95 & 11.34 & 3.585 & 3.16 \\
\hline $\begin{array}{l}\text { Accessibility } \\
\text { to Forest }\end{array}$ & -52.676 & 27.612 & -1.91 & 20.089 & 7.23 & 2.78 & -3.539 & 3.564 & -0.99 \\
\hline Constant & 5.512 & 6.705 & 0.82 & 6.1 & 3.105 & 1.96 & 1.423 & 0.114 & 12.44 \\
\hline
\end{tabular}

Table 13b: Tobit Analysis - District: Shangla, Swat, Upper Dir 


\begin{tabular}{|c|c|c|c|c|c|c|c|c|c|}
\hline \multirow{3}{*}{$\begin{array}{l}\text { Dependent } \\
\text { Variable } \\
\text { Districts } \\
\text { Independent } \\
\text { Variable }\end{array}$} & \multicolumn{9}{|c|}{ Fuelwood used by Household. Tobit Analysis } \\
\hline & \multicolumn{3}{|l|}{ Shangla } & \multicolumn{3}{|l|}{ Swat } & \multicolumn{3}{|l|}{ Upper Dir } \\
\hline & Coefficient & $\begin{array}{l}\text { Std. } \\
\text { Err. }\end{array}$ & $\begin{array}{l}\mathrm{t}- \\
\text { value }\end{array}$ & Coefficient & $\begin{array}{l}\text { Std. } \\
\text { Err. }\end{array}$ & $\begin{array}{l}\mathrm{t}- \\
\text { value }\end{array}$ & Coefficient & $\begin{array}{l}\text { Std. } \\
\text { Err. }\end{array}$ & $\begin{array}{l}\mathrm{t}- \\
\text { value }\end{array}$ \\
\hline $\begin{array}{l}\text { HHS Resident } \\
\text { Duration }\end{array}$ & -0.109 & 2.112 & -0.51 & 0.242 & 0.135 & 1.79 & 0.068 & 0.161 & 0.42 \\
\hline $\begin{array}{l}\text { Household } \\
\text { Size }\end{array}$ & 0.063 & 4.401 & 0.14 & 0.298 & 0.595 & 0.5 & -0.013 & 0.433 & -0.03 \\
\hline Education & -15.84 & 37.633 & -4.21 & -32.635 & 4.401 & -7.41 & -1.361 & 0.769 & -1.77 \\
\hline $\begin{array}{l}\text { Health } \\
\text { Condition }\end{array}$ & -0.189 & 47.197 & -0.04 & -40.749 & 6.535 & -6.24 & -7.969 & 5.844 & -1.36 \\
\hline Wages & 0.024 & 0.295 & 0.81 & -0.665 & 0.214 & -3.11 & 0.208 & 0.277 & 0.75 \\
\hline $\begin{array}{l}\text { NTFP's } \\
\text { Income }\end{array}$ & 0.857 & 0.477 & 1.8 & 0.109 & 0.48 & 0.23 & -0.103 & 0.039 & -2.62 \\
\hline $\begin{array}{l}\text { Other Sources } \\
\text { of Income }\end{array}$ & -0.006 & 0.106 & -0.06 & 0.147 & 0.741 & 0.2 & 0.378 & 0.538 & 0.7 \\
\hline $\begin{array}{l}\text { Agricultural } \\
\text { Efficiency }\end{array}$ & -33.017 & 12.904 & -2.56 & -33.885 & 17.17 & -1.97 & -39.759 & 18.07 & -2.2 \\
\hline $\begin{array}{l}\text { Fuelwood } \\
\text { Prices }\end{array}$ & -0.147 & 0.271 & -5.4 & -0.107 & 0.206 & -0.52 & -0.018 & 0.029 & -0.61 \\
\hline $\begin{array}{l}\text { Access to } \\
\text { Credit }\end{array}$ & -9.894 & 42.56 & -2.32 & 4.426 & 4.765 & 0.93 & -54.668 & 5.201 & -10.51 \\
\hline $\begin{array}{l}\text { Accessibility } \\
\text { to Forest }\end{array}$ & 4.538 & 38.393 & 1.18 & 12.888 & 3.153 & 4.09 & 10.696 & 5.362 & 1.99 \\
\hline Constant & 1.561 & 1.901 & 8.21 & 2.024 & 0.128 & 15.83 & 2.027 & 0.133 & 15.29 \\
\hline
\end{tabular}

\section{Discussion}

It is established that in the face of poverty and lack of alternative income sources, communities in the vicinity of forests strongly rely upon wood, timber, and NTFPs for subsistence. This in turn reinforces the global trend for forest extraction, because it requires little financial and physical capacity, but also due to accessibility to generate HH income (Barber et al., 2014; Assuncao et al., 2013a; Maccedo et al. 2012; Hosonuma et al., 2012; Kissinger et al., 2012; Araujo et al., 2010). Hence, the study confirmed more intensive deforestation and forest degradation patterns in all the study districts, initially in P1 (2000-10 - 0.61, 1.07, 0.16, 0.76, 0.54, and 0.64 from Buner till Upper Dir, respectively). This trend certifies the prevailing trend of up to $74 \%$ loss of forest resources exhaustive deforestation and forests' degradation in other neighboring areas of KP province are experiencing a loss up to $74 \%$ due to incessant clearing and degradation, where people burn wood 858,357 tones in urban areas while 9,541,285 tones in rural areas annually (Irfan et al, 2017).

In P1, forest land was mainly converted to agricultural land (Buner: 8.3ha, Lower Dir: 0.4ha, Shangla: 14.7ha, Swat: 45.5ha, and Upper Dir: 7.2ha), coupled with conversion into grassland, barren land, and settlements. Here, Swat district (relatively) lost more forest area (5110.4ha), followed by Upper Dir (1765.2ha) and Shangla (1300.5ha). In the categories, the forest area converted to settlements and barren land remained second high, i.e., 1897.7ha in Swat, followed by 763.7ha and 583.9ha in Upper Dir and Buner, respectively. This conversion of forest land to other land categories contribute to the global trend of forest land conversion and is posing severe concerns for the regional and global societies (Qasim et al., 2013, 2011). Similarly, in P2 (2010-17), forest area was mainly converted into grassland (Buner: 28422.6ha and Swat 16967.3ha). 
In the same way, settlement expansion on forest land was seen in district Malakand (476.3ha - highest), followed by district Swat (394.3ha) and Shangla (359.2ha).

The resultant biomass loss due to deforestation and forests' degradation was $6.65 \mathrm{Tg}$ that ended up in 24.34 tons of $\mathrm{CO}_{2}$ into the open atmosphere between 2000-17. It was linked to $\mathrm{HH}$ fuelwood and commercial wood harvesting, where the losses of biomass and carbon stock due to $\mathrm{HH}$ activities were $7155.58 \mathrm{Mg}$ and $3363.12 \mathrm{Mg}$, respectively validating the study of Ahmed et al., (2014) and Rehman et al., (2014). This intense pressure on forest resources was derived from population growth, agricultural expansion, and residential constructions. Yet, poor agricultural output and resultant insufficient income diverted the localities towards un-sustained deforestation and forest degradation. Although more education and health status played an important role in fewer forests (and forest products) extraction as found in other societies confirming the study of Nazir and Olabisi (2015), but low off-farm wages, increased family size, no/limited access to credit, etc. were the factors undermining the positive contribution of education to address the issue.

\section{Conclusion}

The state of forests in Pakistan has been under the intense pressure of extraction of forest wood and NTFPs, especially in the highest forest-covered areas of Malakand Division. The rich confiner forests were significantly deforested in a period of 17 years. The study confirmed extensive LULCC between $2000-10$ at the rate of $0.63 \%$ and then $0.87 \%$ in 2017 due to fuelwood collection, exaggerated by the hike in prices of forest products, increased demand for fuel and construction wood, illegal extraction, agricultural expansion, population growth, increase in settlements, etc. Other societal factors contributed to the problem were easy accessibility to forests, no/limited access to credit, inefficiency agriculture, lack of alternative energy, and income generation activities. Although, education and degrading health conditions of the forests' dependent communities have decreased this dependency, yet they could not hamper the rate of exploitation.

The state of forests in Pakistan holds contradictive and conflicting evidence. The government has taken several steps to address the issue like the development of the National Forest Monitoring System (NFMS), the establishment of sub-national REDD+ units at the provincial level (KP), tree plantation under the Billion Tree Tsunami, the establishment of national parks, green growth initiative, etc. (Baig and Al-Subaiee, 2011). These efforts were to invert the flow of forest dependency through increasing other livelihood prospects and thereupon decreasing poverty. However, the findings of the independent researches question the execution of all such efforts geared in the protection of forest cover. So, this research study suggests that the concerned public stakeholders provide a supplementary source of energy. As the area has a high potential for biomass gas for which lack of credit and financial assistance is the main hurdle, the provision of technical knowledge and tools can help the locality to execute village-based biomass gas plants to overcome the local energy needs. In order to meet international agreements such as REDD ${ }^{+}$forest dependency must be reduced by providing alternative sources of income, where agricultural productivity can be increased through agricultural mechanization on the existing farmland. Lastly, for the conservation of the limited forest resources, property rights should be executed to stop any further deforestation and forest degradation in the study area.

\section{Declarations}

\section{Ethical Approval}

All ethical standard has followed in this research paper. No formal approval is required.

\section{Consent to Participate}

The research is not on human and animal subjects.

\section{Consent to Publish}


We are willing to publish the research paper in Environmental Science and Pollution Research.

\section{Authors Contributions}

Conceptualization, Muhammad Tufail, Shahzad Alvi, Umer Khayyam and Ather Maqsood Ahmed; methodology and software, Muhammad Tufail, Shahzad Alvi, Umer Khayyam and Ather Maqsood Ahmed; validation, Muhammad Tufail, Shahzad Alvi, Umer Khayyam and Ather Maqsood Ahmed; formal analysis, Muhammad Tufail, Shahzad Alvi, Umer Khayyam and Ather Maqsood Ahmed writing-original draft preparation, Muhammad Tufail, Shahzad Alvi, Umer Khayyam and Ather Maqsood Ahmed

\section{Funding}

No funding is involved in this research.

\section{Competing Interests}

There is no competing interest in the manuscript.

\section{Availability of data and materials}

Data is available from authors on request.

\section{References}

Ahmad, A., Liu, Q. J., Nizami, S. M., Mannan, A., \& Saeed, S. (2018). Carbon emission from deforestation, forest degradation and wood harvest in the temperate region of Hindukush Himalaya, Pakistan between 1994 and 2016. Land use policy, 78, 781-790.

Ahmad, A., Mirza, S. N., \& Nizami, S. M. (2014). Assessment of biomass and carbon stocks in coniferous forest of Dir Kohistan, KPK. Pakistan Journal of Agricultural Sciences, 51(2).

Ahmad, S., \& Abbasi, Q. (2011). Assessment of Forest Cover Decline in Pakistan: A GIS Perspective. International Journal of Environmental ..., 2(July), 220-227. Retrieved from http://www.indianjournals.com/ijor.aspx? target=ijor:ijes\&volume=2\&issue=1\&article=023.

Ali, G., Qamer, F. M., Gilani, H., Shehzad, K., \& Abbas, S. (2015). Status of the Forest Cover Assessment and Monitoring System in Pakistan in the Context of REDD. Multi-Scale Forest Biomass Assessment and Monitoring in the Hindu Kush Himalayan Region: A Geospatial Perspective, 59.

Ali, J., \& Benjaminsen, T. A. (2004). Fuelwood, timber, and deforestation in the Himalayas. Mountain Research and Development, 24(4), 312-318.

Araujo, C., Bonjean, C. A., Combes, J. L., Motel, P. C., \& Reis, E. J. (2011). Does land tenure insecurity drive deforestation in the Brazilian Amazon? CERDI, Etudes et Documents, E 2010.13

Arima, E. Y., Richards, P., Walker, R., \& Caldas, M. M. (2011). Statistical confirmation of indirect land-use change in the Brazilian Amazon. Environmental Research Letters, 6(2), 024010.

Assunção, J., Gandour, C., Rocha, R., \& Rocha, R. (2013). Does credit affect deforestation? Evidence from a rural credit policy in the Brazilian Amazon. Climate Policy Initiative, Rio de Janeiro, Brazil.

Baccini A, Goetz SJ, Walker WS, et al. Estimated carbon dioxide emissions from tropical deforestation improved by carbondensity maps. Nature Climate Change. 2012; 2: 182-185

Page $17 / 29$ 
Bahugunaa, V. K., Swaminathb, M. H., Tripathic, S., Singhd, T. P., Rawate, V. R. S., \& Rawatf, R. S. (2016). Revisiting forest types of India. International Forestry Review, 18(2), 135-145.

Balogh, J. M. (2020). The Role of Agriculture in Climate Change: A Global Perspective. International Journal of Energy Economics and Policy, 10(2), 401.

Barber, C. P., Cochrane, M. A., Souza Jr, C. M., \& Laurance, W. F. (2014). Roads, deforestation, and the mitigating effect of protected areas in the Amazon. Biological Conservation, 177, 203-209.

Barona, E., Ramankutty, N., Hyman, G., \& Coomes, O. T. (2010). The role of pasture and soybean in deforestation of the Brazilian Amazon. Environmental Research Letters, 5(2), 024002.

Boucher, D., Elias, P., Lininger, K., May-Tobin, C., Roquemore, S., \& Saxon, E. (2011). The root of the problem. What is driving tropical deforestation today? Tropical Forest and Climate Initiative Union of Concerned Scientists.

Celine, P. Mayaux, A. Verhegghen, C. Bodart, M. Christophe, P. Defourny (2013) National forest cover change in Congo Basin: deforestation, reforestation, degradation and regeneration for the years 1990, 2000 and 2005 Glob. Change Biol., pp. 11731187

Coulston, J. W., Wear, D. N., \& Vose, J. M. (2015). Complex forest dynamics indicate potential for slowing carbon accumulation in the southeastern United States. Scientific reports, 5, 8002.

De Espindola, G. M., De Aguiar, A. P. D., Pebesma, E., Câmara, G., \& Fonseca, L. (2012). Agricultural land-use dynamics in the Brazilian Amazon based on remote sensing and census data. Applied Geography, 32(2), 240-252.

Duveiller, G., Defourny, P., Desclée, B., \& Mayaux, P. (2008). Deforestation in Central Africa: Estimates at regional, national, and landscape levels by advanced processing of systematically-distributed Landsat extracts. Remote sensing of environment, 112(5), 1969-1981.

Eliasch, J. (2008). Climate change: financing global forests: the Eliasch review. Earthscan.

Epule, E. T., Peng, C., Lepage, L., \& Chen, Z. (2014). Policy options towards deforestation reduction in Cameroon: An analysis based on a systematic approach. Land use policy, 36, 405-415.

Espírito-Santo, F. D., Gloor, M., Keller, M., Malhi, Y., Saatchi, S., Nelson, B., ... \& Palace, M. (2014). Size and frequency of natural forest disturbances and the Amazon forest carbon balance. Nature communications, 5(1), 1-6.

FAO, (2016) Land Cover Atlas of Pakistan The Khyber Pakhtunkhwa Province and Federally Administered Tribal Areas: A joint publication by FAO, SUPARCO and Crop Reporting Service, Government of KP and FATA.

FAO. (2009). Pakistan forestry outlook study-Asia-Pacific forestry sector outlook study II. working paper no. APFSOS II/WP/2009/28. Ministry of Environment, Government of Pakistan, Food and Agriculture Organization of the United Nations Regional Office for Asia and the Pacific, Bangkok.

FAO. 2010 Global Forest Resources Assessment 2010 FAO Forestry Paper 163

FAO. 2015 Global Forest Resources Assessment Rome: Food and Agriculture Organization ISBN 978-92-5-108826-5.

Food and Agriculture Organization. (2007). The World's Mangroves 1980-2005: a thematic study prepared in the framework of the Global Forest Resources Assessment 2005.

G.P. Dkamela (2010) The context of REDD+ in Cameroon: drivers, agents and institutions Occasional Paper 57, CIFOR, Bogor, Indonesia 
Gautam, A. P., Webb, E. L., Shivakoti, G. P., \& Zoebisch, M. A. (2003). Land use dynamics and landscape change pattern in a mountain watershed in Nepal. Agriculture, Ecosystems \& Environment, 99, 83-96.

Gayen, A., \& Saha, S. (2018). Deforestation probable area predicted by logistic regression in Pathro river basin: a tributary of Ajay River. Spatial Information Research, 26(1), 1-9.

Geist, H. J., \& Lambin, E. F. (2001). What drives tropical deforestation. LUCC Report series, 4, 116.

Gorte, R.W and Sheikh, P. A (2010) Deforestation and Climate Change, Congressional Research Service, March 24, 2010.

Gov't of Pakistan Census (2017). Province wise provisional results of the census - 2017 administrative units' population 2017 khyber Pakhtunkhwa 1-18.

Government of Pakistan (2015). Action Plan for the Implementation of the National Forest Monitoring System of Pakistan. Policy Draft

Government of the Khyber Pakhtunkhwa, Crop Reporting Services Statistics (2015-2016).

Green, G., Schweik, C. M., \& Hanson, M. (2002). Radiometric calibration of LANDSAT multi-spectral scanner and thematic mapper images: Guidelines for the global change community. Center for the Study of Institutions, Population, and Environmental Change (CIPEC), Indiana University, CWP-02-03. Bloomington.

Hansen, M. C., Potapov, P. V., Moore, R., Hancher, M., Turubanova, S. A. A., Tyukavina, A., \& Kommareddy, A. (2013). Highresolution global maps of 21 st-century forest cover change. science, 342(6160), 850-853.

Haq, F., Rahman, F., Tabassum, I., Ullah, I., \& Sher, A. (2018). Forest Dilemma in the Hindu Raj Mountains Northern Pakistan: Impact of Population Growth and Household. Small-Scale Forestry. https://doi.org/10.1007/s11842-018-9390-9.

Haripriya, G.S. 2000. Estimates of biomass in Indian forests. Biomass and Bioenergy 19: 245-258.

Herold, M., Angelsen, A., Verchot, L., Wijaya, A., Ainembabazi, J.H., (2012). A stepwise framework for developing REDD+ reference levels. In: Angelsen, A., Brockhaus, M., Sunderlin, W.D., Verchot, L.V. (Eds.), Analysing REDD+: Challenges and Choices. Center for International Forestry Research (CIFOR), Bogor, Indonesia, pp. 279-300.

Hosonuma, N., Herold, M., De Sy, V., De Fries, R. S., Brockhaus, M., Verchot, L., ... \& Romijn, E. (2012). An assessment of deforestation and forest degradation drivers in developing countries. Environmental Research Letters, 7(4), 044009.

Houghton, R. A. (2003). Revised estimates of the annual net flux of carbon to the atmosphere from changes in land use and land management 1850-2000. Tellus B: Chemical and Physical Meteorology, 55(2), 378-390.

Insaidoo, T. F.G., Ros-Tonen, M. A.F., Hoogenbosch, L. and Acheampong, E. (2012) Addressing Forest Degradation and Timber Deficits in Ghana, ETFRN News 53: April 2012

IPCC. 2006. Guidelines for National Greenhouse Gas Inventories. Available online with updates at www.ipccnggip.iges.or.jp/public/2006gl/index.html

Irfan, M., Cameron, M. P., \& Hassan, G. (2018). Household energy elasticities and policy implications for Pakistan. Energy Policy, 113(October 2017), 633-642. https://doi.org/10.1016/j.enpol.2017.11.041

Joshua, P., Christopher, W., Aaron, W., (2017). Implications of land-use change on forest carbon stocks in the eastern United States. Environ. Res. Lett. 12, 024011 
Keenan, R. J., Reams, G. A., Achard, F., de Freitas, J. V., Grainger, A., \& Lindquist, E. (2015). Dynamics of global forest area: Results from the FAO Global Forest Resources Assessment 2015. Forest Ecology and Management, 352, 9-20.

Khan, A. N., \& Ali, A. (2015). Desertification Risk Reduction Approaches in Pakistan. In Disaster Risk Reduction Approaches in Pakistan (pp. 161-173). Springer, Tokyo.

Kissinger G., (2012). Corporate social responsibility and supply agreements in the agricultural sector Decreasing land and climate pressures. CCAFS Working Paper no. 14 Copenhagen, Denmark.

L. Bernstein, P. Bosch, O. Canziani, Z. Chen, R. Christ, K. Riahi (2008) Climate Change (2007): Synthesis Report IPCC,Geneva, Switzerland (104 pp.)

Lele, N., Joshi, P.K., (2009). Analyzing deforestation rates, spatial forest cover changes, and identifying critical areas of forest cover changes in North-East India during 1972-1999. Environ. Monit. Assess. 156 (1-4), 159.

Lopes, C., Leite, A., \& Vasconcelos, M. J. (2019). Open-access cloud resources contribute to mainstream REDD+: The case of Mozambique. Land Use Policy, 82, 48-60.

López-Carr, D., \& Burgdorfer, J. (2013). Deforestation drivers: population, migration, and tropical land use. Environment: Science and Policy for Sustainable Development, 55(1), 3-11.

Macedo, M. N., DeFries, R. S., Morton, D. C., Stickler, C. M., Galford, G. L., \& Shimabukuro, Y. E. (2012). Decoupling of deforestation and soy production in the southern Amazon during the late 2000s. Proceedings of the National Academy of Sciences, 109(4), $1341 \mathrm{e} 1346$.

Megevand, C., Mosnier, A., Hourticq, J., Sanders, K., Doetinchem, N., \& Streck, C. (2013). Deforestation trends in the Congo Basin: reconciling economic growth and forest protection. The World Bank.

Meyfroidt, P. (2016). Approaches and terminology for causal analysis in land systems science. Journal of Land Use Science, 11(5), 501-522.

Meyfroidt, P., Lambin, E. F., Erb, K. H., \& Hertel, T. W. (2013). Globalization of land use: distant drivers of land change and geographic displacement of land use. Current Opinion in Environmental Sustainability, 5(5), 438-444.

Mitsuda, Y., Ito, S., (2011) A review of spatial-explicit factors determining spatial distribution of land use/land-use change. Landscape Ecol Eng 7, 117-125. https://doi.org/10.1007/s11355-010-0113-4.

Nazir, N., \& Majid, I. (2010). An Analysis of Socioeconomic Factors Causing Deforestation in Hazara Division, Khyber Pakhtunkhwa. The Pakistan Journal of Social Issues, 2, 19.

Nazir, N., \& Olabisi, L. S. (2015). Forest Area and Land Use Change in Pakistan: A System Dynamics Approach. Proceedings of the 33rd International Conference of the System Dynamics Society.

Nizami, S.M. 2012. The inventory of the carbon stocks in sub-tropical forest of Pakistan for reporting under Kyoto Protocol. J. For. Res. 23(2): 377-384.

Olofsson, P., Foody, G.M., Herold, M., Stehman, S.V., Woodcock, C.E., Wulder, M.A., 2014. Good practices for estimating area and assessing accuracy of land change. Rem. Sens. Environ. 148, 42-57.

Olsen, N., \& Bishop, J. (2009). The financial costs of REDD: evidence from Brazil and Indonesia. IUCN.

Owusu-Sekyere, J. D., Alhassan, M., \& Nyarko, B. K. (2011). Assessment of climate shift and crop yields in the Cape Coast area in the Central Region of Ghana. ARPN Journal of Agricultural and Biological Science, 6(2), 49-54. 
Pak-Swiss Integrated Natural Resource Management Project (INRMP) on "timber harvesting ban in NWFP, Pakistan. Pp 1237 ISBN: 969-9082-02-x

Pan, Y., Birdsey, R. A., Fang, J., Houghton, R., Kauppi, P. E., Kurz, W. A., ... \& Ciais, P. (2011). A large and persistent carbon sink in the world's forests. Science, 333(6045), 988-993.

Pandey, S. S., Cockfield, G., \& Maraseni, T. N. (2016). Assessing the roles of community forestry in climate change mitigation and adaptation: A case study from Nepal. Forest Ecology and Management, 360, 400-407.

Pfaff, A., Robalino, J., Walker, R., Aldrich, S., Caldas, M., Reis, E., ... \& Kirby, K. (2007). Road investments, spatial spillovers, and deforestation in the Brazilian Amazon. Journal of Regional Science, 47(1), 109-123.

Philip, M. S. (1994): Measuring Trees and Forests. Second edition. CAB, International, Wallingford.

Qamer, F. M., Abbas, S., Saleem, R., Shehzad, K., Ali, H., \& Gilani, H. (2012). Forest cover change assessment in conflictaffected areas of northwest Pakistan: The case of Swat and Shangla districts. Journal of Mountain Science, 9(3), 297-306.

Qamer, F. M., Shehzad, K., Abbas, S., Murthy, M. S. R., Xi, C., Gilani, H., \& Bajracharya, B. (2016). Mapping deforestation and forest degradation patterns in western Himalaya, Pakistan. Remote Sensing, 8(5), 385.

Qasim, M., Hubacek, K., Termansen, M., \& Fleskens, L. (2013). Modelling land use change across elevation gradients in district Swat, Pakistan. Regional Environmental Change, 13(3), 567-581. https://doi.org/10.1007/s10113-012-0395-1

Qasim, M.; Hubacek, K.; Termansen, M.; Khan, A. Spatial and temporal dynamics of land use pattern in District Swat, Hindu Kush Himalayan region of Pakistan. Appl. Geogr. 2011, 31, 820-828.

Quéré, C. L., Moriarty, R., Andrew, R. M., Canadell, J. G., Sitch, S., Korsbakken, J. I., ... \& Houghton, R. A. (2015). Global carbon budget 2015. Earth System Science Data, 7(2), 349-396.

Rahman, F., Haq, F., Tabassum, I., \& Ullah, I. (2014). Socio-economic drivers of deforestation in Roghani Valley, Hindu-Raj Mountains, Northern Pakistan. Journal of Mountain Science, 11(1), 167-179.

Reddy, C.S., Rao, K.R.M., Pattanaik, C., Joshi, P.K., (2009). Assessment of large-scale deforestation of Nawarangpur district, Orissa, India: a remote sensing-based study. Environ. Monit. Assess. 154 (1-4), 325.

S. S., Abbasi, Q. U. A., Jabeen, R., \& Shah, M. T. (2012). Decline of Conifer forest cover in Pakistan: A GIS approach. Pakistan Journal of Botany, 44(2), 511-514.

Saeed, S., Ashraf, M.I., Ahmad, A., Rahman, Z., 2016. The bela forest ecosystem of district jehlum, a potential carbon sink. Pak. J. Bot. 48, 121-129.

Shehzad, K., Qamer, F. M., Murthy, M. S. R., Abbas, S., \& Bhatta, L. D. (2014). Deforestation trends and spatial modeling of its drivers in the dry temperate forests of northern Pakistan-A case study of Chitral. Journal of Mountain Science, 11(5), 11921207.

Stern, N. H., Peters, S., Bakhshi, V., Bowen, A., Cameron, C., Catovsky, S., ... \& Garbett, S. L. (2006). Stern Review: The economics of climate change (Vol. 30, p. 2006). Cambridge: Cambridge University Press.

Stibig, H. J., Achard, F., Carboni, S., Rasi, R., \& Miettinen, J. (2014). Change in tropical forest cover of Southeast Asia from 1990 to 2010. Biogeosciences, 11(2), 247.

Suleri, A. Q. (2002). Regional study on forest policy and institutional reform; Final Report of the Pakistan Case Study. Asian Development Bank, Manila.

Page 21/29 
Tariq, M., Rashid, M., \& Rashid, W. (2014). Causes of deforestation and climatic changes in Dir Kohistan. Journal of Pharmacy and Alternative Medicine, 3(2), 28-37.

Tegegne, Y.T., Lindner, M., Fobissie, K., Kanninen, M., (2016). Evolution of drivers of deforestation and forest degradation in the Congo Basin forests: exploring possible policy options to address forest loss. Land Use Policy 51, 312-324.

Thompson, M. C., Baruah, M., \& Carr, E. R. (2011). Seeing REDD+ as a project of environmental governance. environmental science \& policy, 14(2), 100-110.

Tufail M., Ahmed A.M., Alvi S. (2021): Conservation of forest through provision of alternative sources of income; an evidence from rural households in northern Pakistan. J. For. Sci., 67: 36-50.

Tufail, M., Ahmed. M. A., and Ali. Junaid (2020) "Assessment of Economic Values of Goods and Services Provided by the Conifer Forest Ecosystem in Khyber Pakhtunkhwa Province of Pakistan. Conference Proceeding18th RSEP International Economics, Finance \& Business Conference, 26-27 August 2020, Istanbul-Turkey

UNEP, \& ICIMOD. (1998). Environment assessment technical reports: Landcover assessment and monitoring Pakistan. Bangkok: United Nations Environment Program.

Van der Werf, G. R., Morton, D. C., DeFries, R. S., Olivier, J. G., Kasibhatla, P. S., Jackson, R. B., \& Randerson, J. T. (2009). CO 2 emissions from forest loss. Nature Geoscience, 2(11), 737.

WMO. (2018). Greenhouse gas bulletin: The state of the greenhouse gases in the atmosphere based on global observations through 2017.

World Development Report (2003). Sustainable Development in a Dynamic World: Transforming Institutions, Growth, and Quality of Life. World Bank, Washington, DC.

Zhang, L. X., Wang, C. B., \& Song, B. (2013). Carbon emission reduction potential of a typical household biogas system in rural China. Journal of cleaner production, 47, 415-421.

Zhou, D., Liu, S., Oeding, J., Zhao, S., (2013). Forest cutting and impacts on carbon in the eastern United States. Sci. Rep. 3, 3547. https://doi.org/10.1038/srep03547.

\section{Figures}




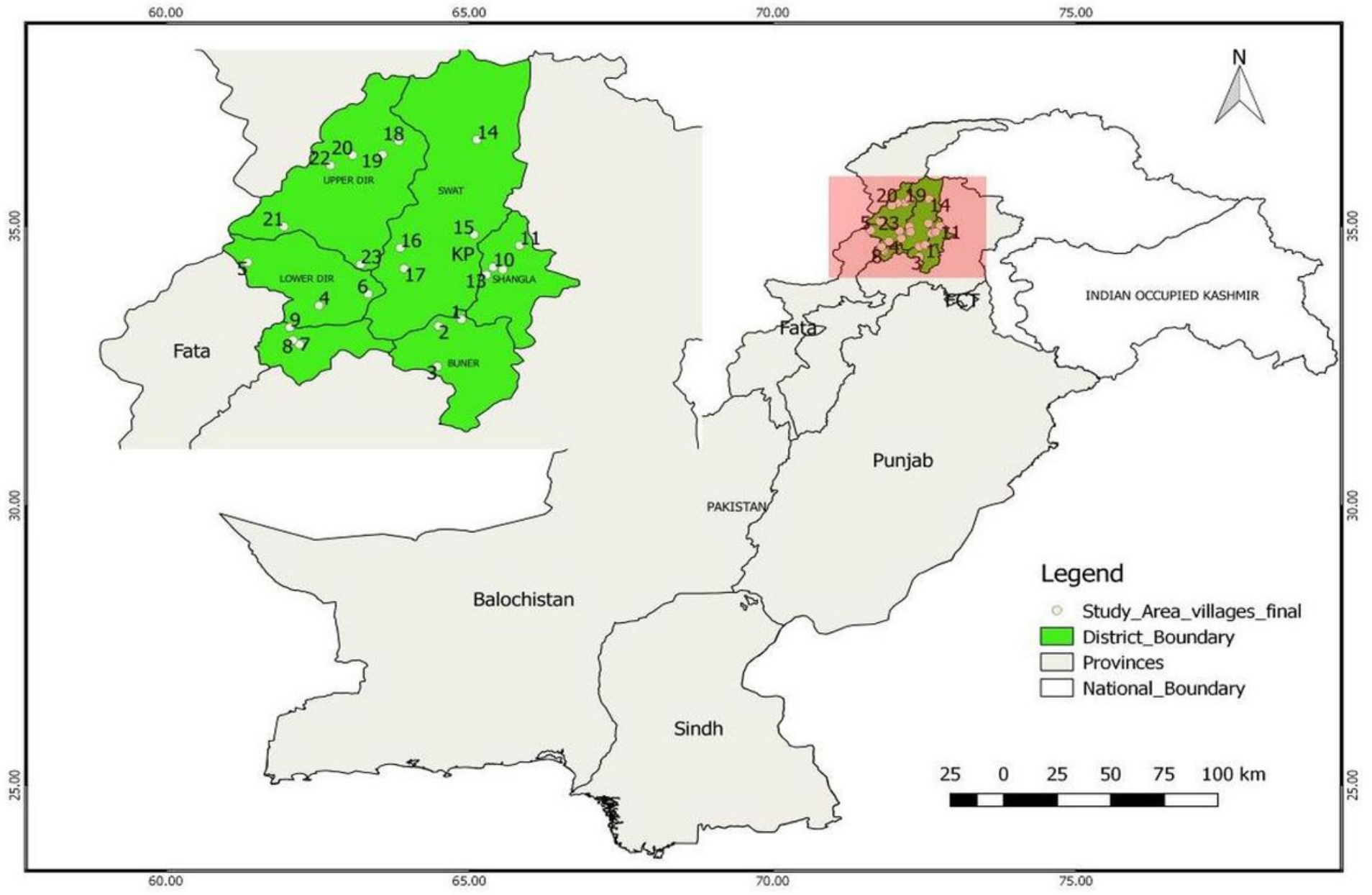

Figure 1

Study area map. Note: The designations employed and the presentation of the material on this map do not imply the expression of any opinion whatsoever on the part of Research Square concerning the legal status of any country, territory, city or area or of its authorities, or concerning the delimitation of its frontiers or boundaries. This map has been provided by the authors. 


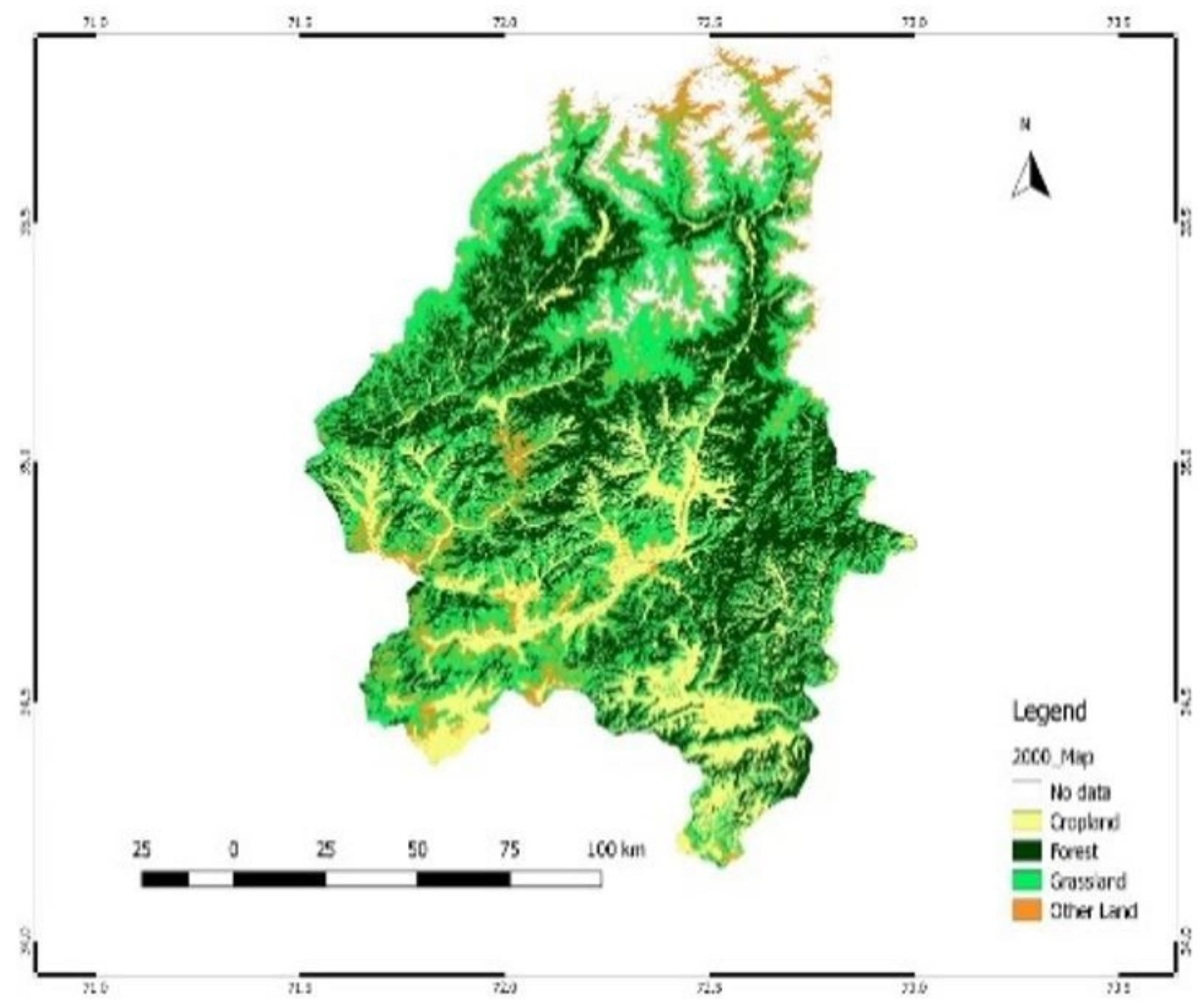

Figure 2

LULC (2000) Note: The designations employed and the presentation of the material on this map do not imply the expression of any opinion whatsoever on the part of Research Square concerning the legal status of any country, territory, city or area or of its authorities, or concerning the delimitation of its frontiers or boundaries. This map has been provided by the authors. 


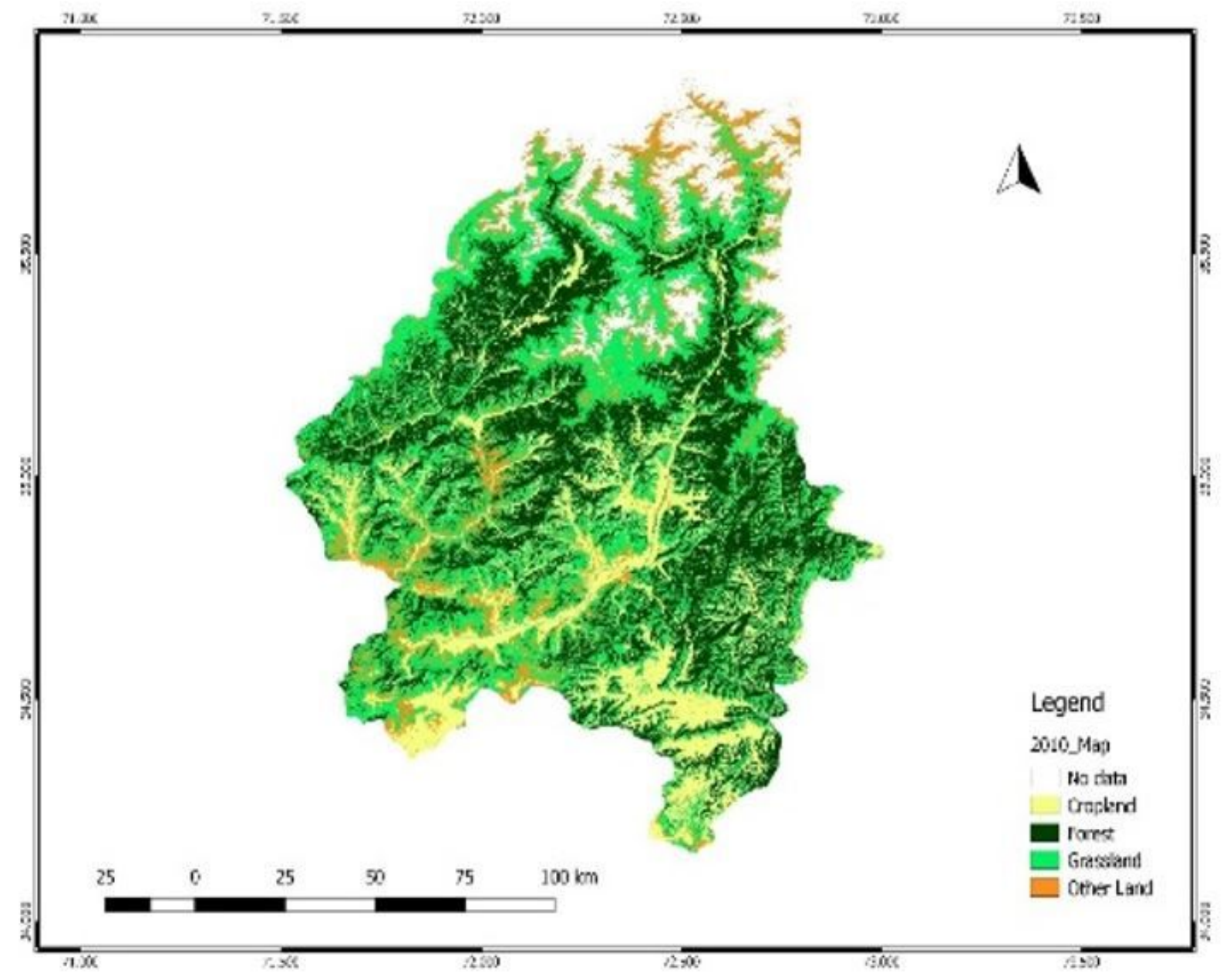

\section{Figure 3}

LULC (2010) Note: The designations employed and the presentation of the material on this map do not imply the expression of any opinion whatsoever on the part of Research Square concerning the legal status of any country, territory, city or area or of its authorities, or concerning the delimitation of its frontiers or boundaries. This map has been provided by the authors. 


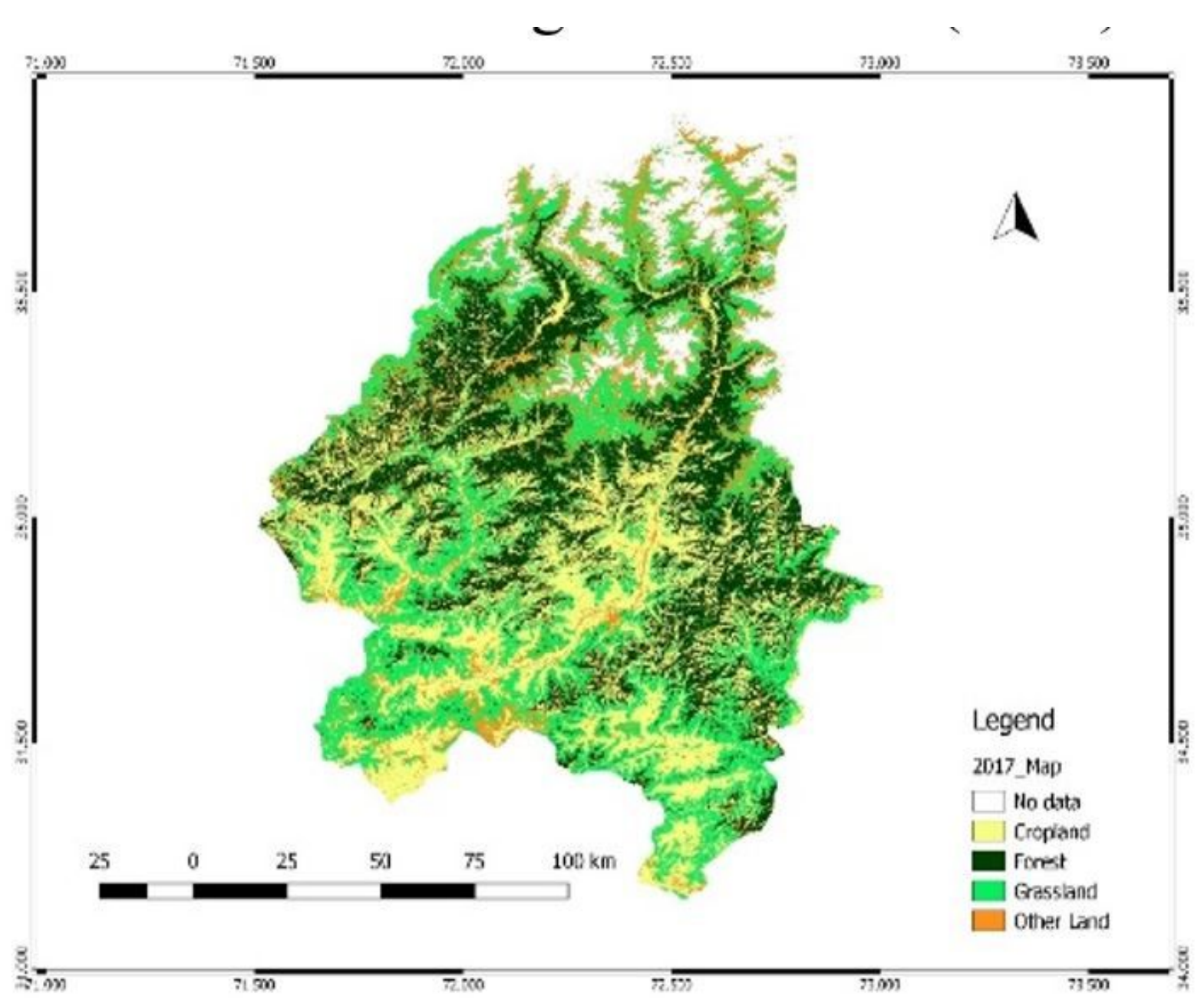

Figure 4

LULC (2017) Note: The designations employed and the presentation of the material on this map do not imply the expression of any opinion whatsoever on the part of Research Square concerning the legal status of any country, territory, city or area or of its authorities, or concerning the delimitation of its frontiers or boundaries. This map has been provided by the authors. 


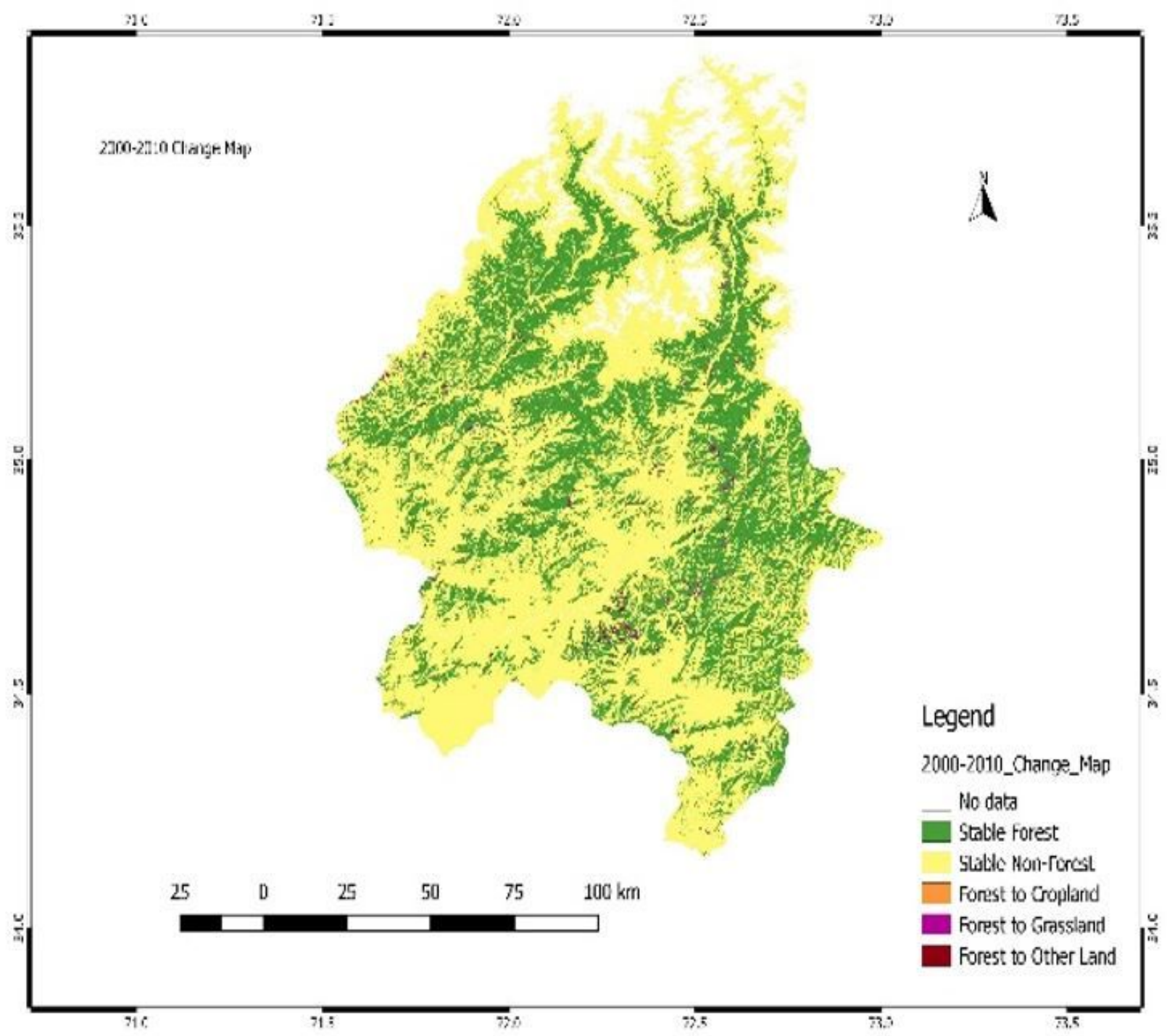

Figure 5

LULCC (2000-2010) Note: The designations employed and the presentation of the material on this map do not imply the expression of any opinion whatsoever on the part of Research Square concerning the legal status of any country, territory, city or area or of its authorities, or concerning the delimitation of its frontiers or boundaries. This map has been provided by the authors. 


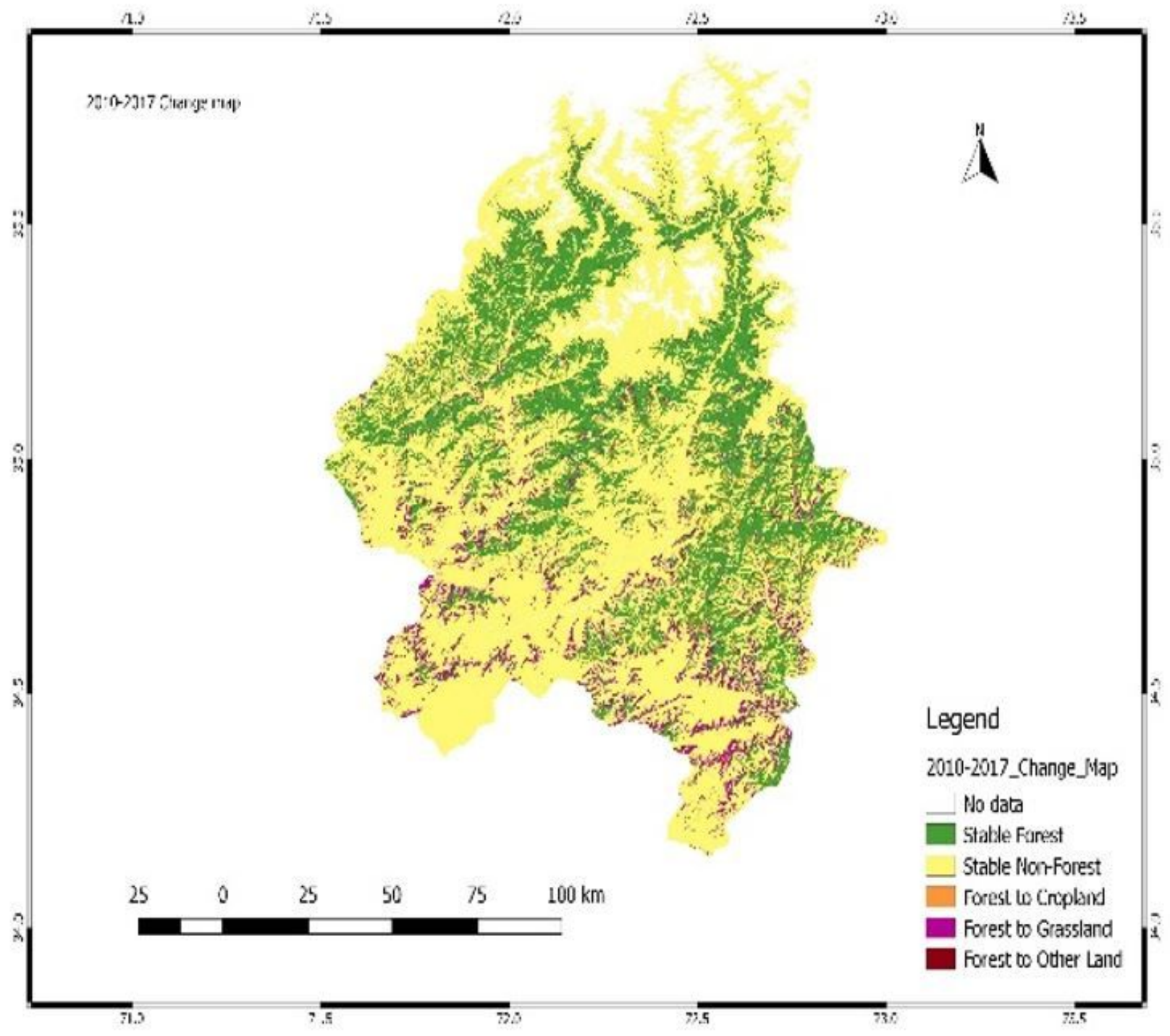

Figure 6

LULCC (2010-2017) Note: The designations employed and the presentation of the material on this map do not imply the expression of any opinion whatsoever on the part of Research Square concerning the legal status of any country, territory, city or area or of its authorities, or concerning the delimitation of its frontiers or boundaries. This map has been provided by the authors. 


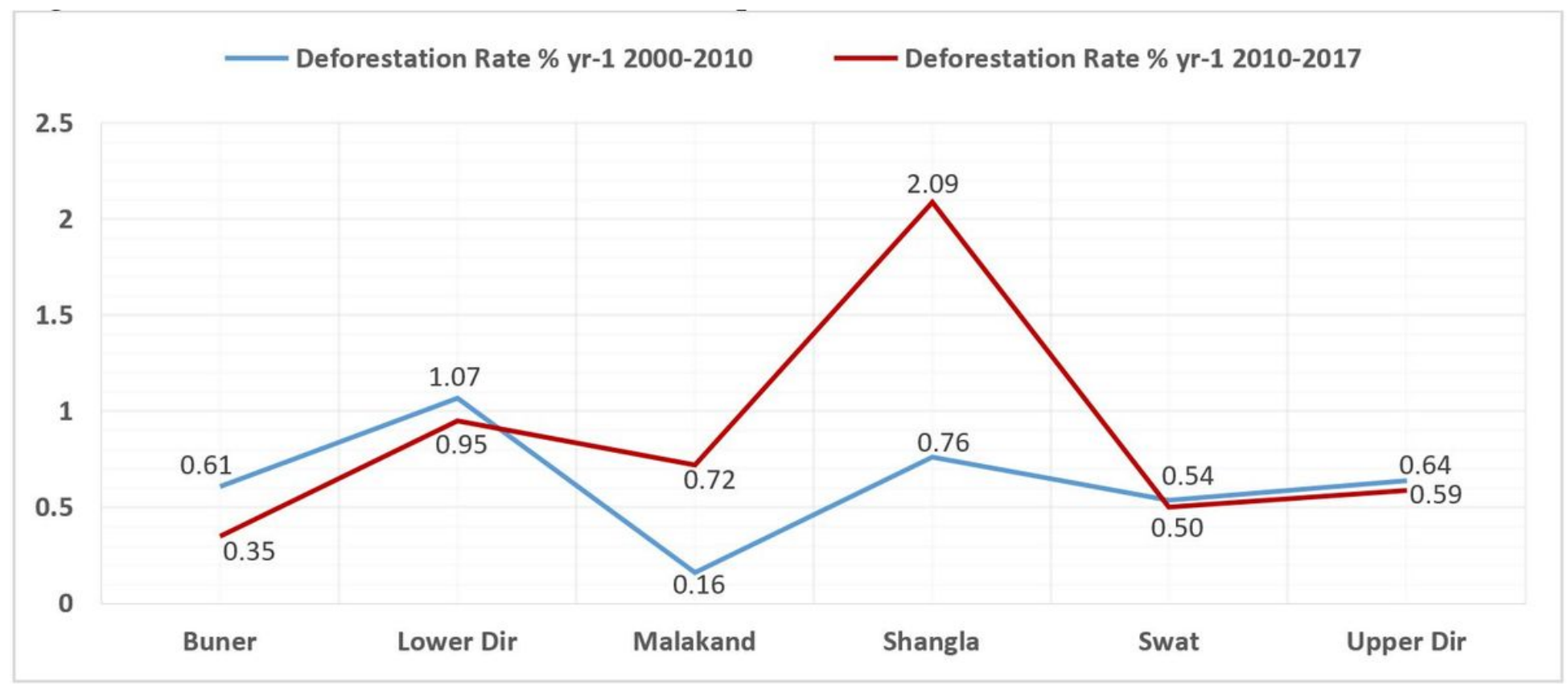

Figure 7

Deforestation rate between the two periods P1 and P2. 